天明・寛政期に括りる江戸幕府大目付職務の一考察

い義盟松郎

や平よに稿

し肥太弓扣は 加後郎之け

し和氏民学る 江 代级石騂

従のよ込幕

来諸りの訴府

の氏着での大

研に手あ処目

究よさる理付

状り䏓。手の

況樣た続天

を々大を明

鑑な貝検宽

圣視付討 寛

れ角

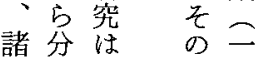

珯析公職七

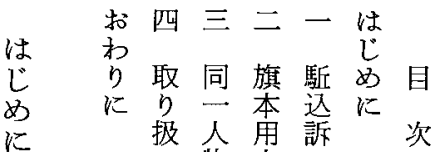

学架々務八

い物人只

のに立取

影上花り

響 省要 扱

馸左心

込 衛

訴

の

取 騲

年这

卡訴

喜件

の深

義

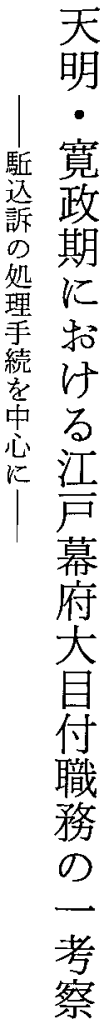

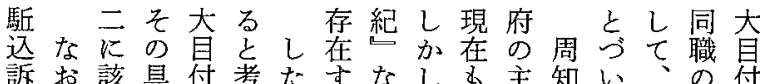

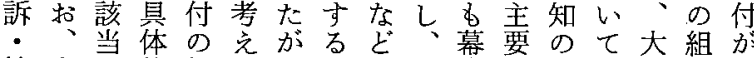
捨小打組 $5 っ こ の$ 分府役ごい目織加 訴稿るな織れてと二析職職とる付・役 なに。職・る。次さ制をくこに構と

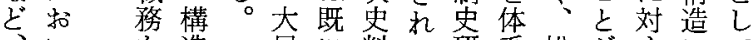

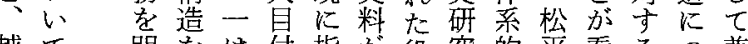
越て 明をは付指少役究的平看る 訴取 5 把、の摘多職にに太取基い任 をり加握伝研さくに多網郎で本てし 個上に卞存究れ用主囉氏き的分た 別壮する過はていいなしのるな析諸

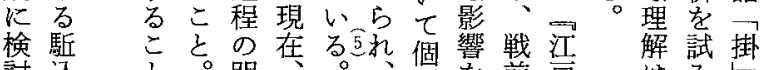
討込と。明、。、別を前户法声 乙訴で二ら二そ別与に時宁たや

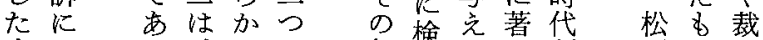
小っる叙倹る党制平の判 早い上立課述討古れ度太で制

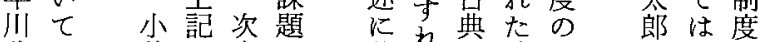
欣は稿に史学若れ的論研氐なの 吾、の女料内午格名考究少小解 兵駕試とに包の著で叴成こ明

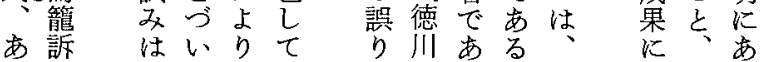
が実るが幕字とり 


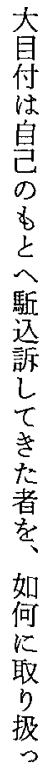

はにた分とば析をすたなり視い中福やい 特大析比、を処るがらさ調、しを・諸は

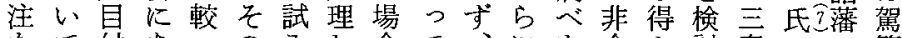

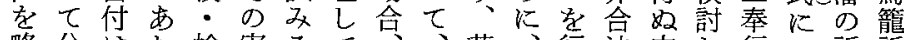
略分はた検奏るて若行法内し行上訴訴 自馸格格り討態必い上非年大行詓内容

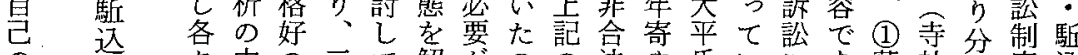
の訴々中の三て解がのの法や氏

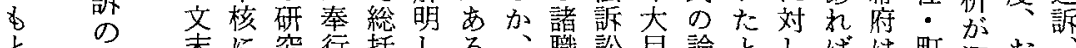

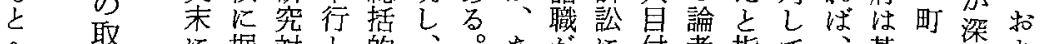

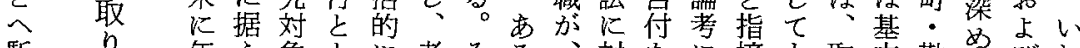
馸扱年党象とに老そる、対なに摘名取本勘らびる

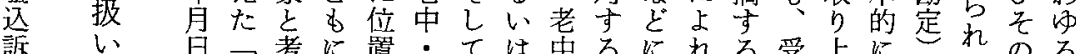

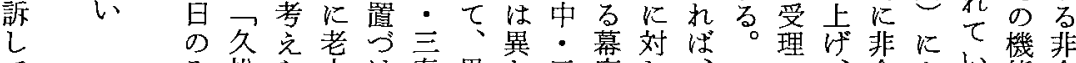

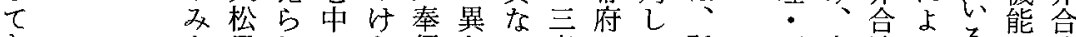
きを王好ょな行なる奉のて駈不番法るるに法

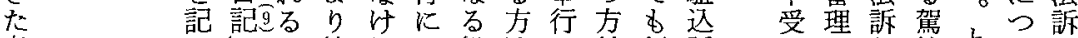
しᄂの箱れよ処法と針行訴 たよで訴ばる理で類をわ学れ老判始受訴わてに 理を訟籠 と い訟 引る8の 5 込行応のらた中断し理䮖け明点 用。審な訴っし方かと。方たし込大をを 叙な查いのてた法にさ三る。な訴平試当

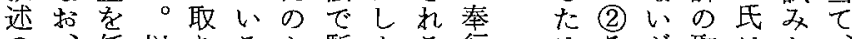
の任以りるか馸よる行め方取はた 場小さ㠿扱な、迅 合稿礼のいら分訴としみ取ゆ黙扱老平府

八き人国本一駈そは四め值招五訳天付学た 更次州る。住件这れ持年る注い年は明へ表。の

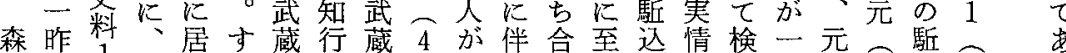

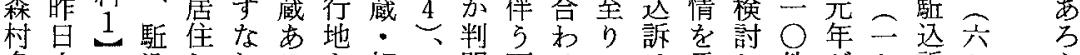

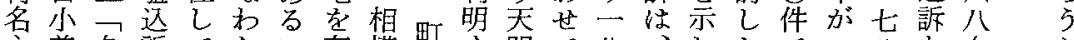

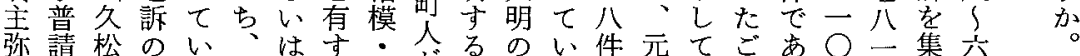

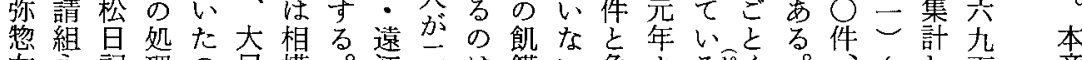

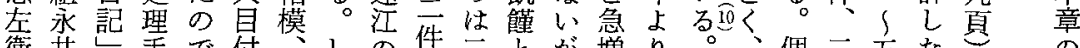

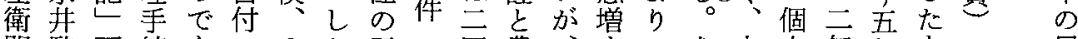

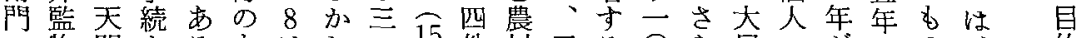

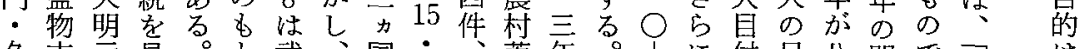

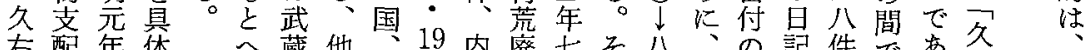

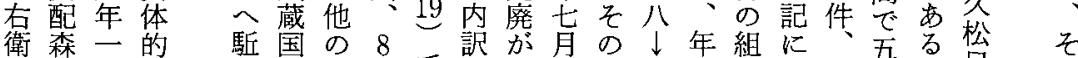
門権 $○$ 込の事はでは関に理五間織依三五。旦の

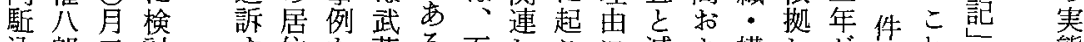
込郎三討す住を蔵る。百しこに減よ構しが扎態

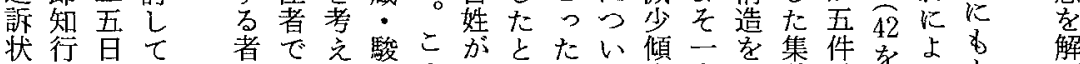

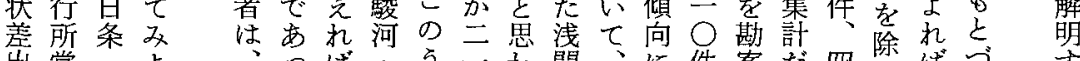

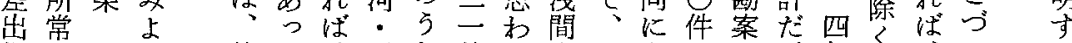
候州 5 基た 、近ち、件れ山明市の拉年

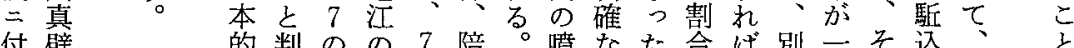

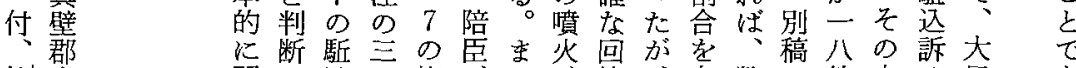
例高関で込历旗がた、答、占数に件内は自内 


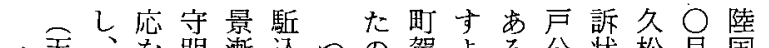

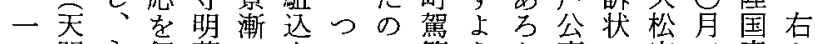

一盟永伺薰は人いで籠 55 事に定二真か

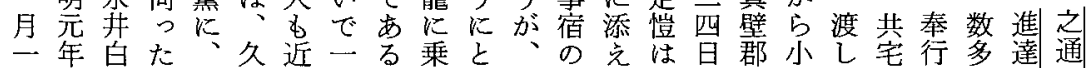

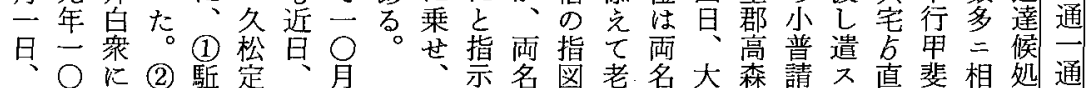

大月引々込愷引二用しをに中古直村組

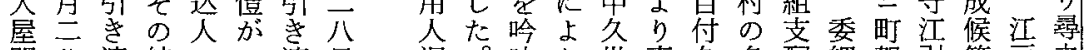

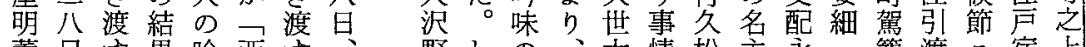

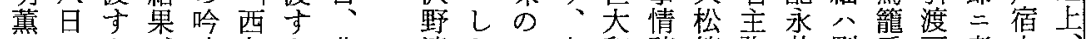
よ・ょ味丸と曲清たた大和聴筑弥井別乗可者之

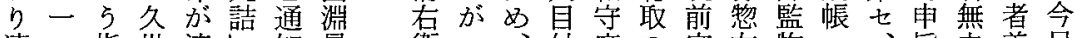

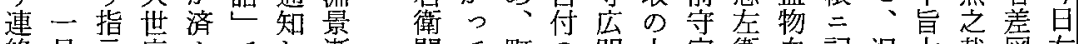
絡月示広んでし漸門て町の明上定衛白記沢大哉図右 を一を明だあたは势、奉もに愷門衆ス野和、い訴

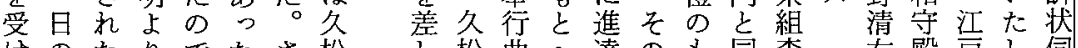
けのたりでたさ松松曲会の洋の同㷊右殿吉し伺

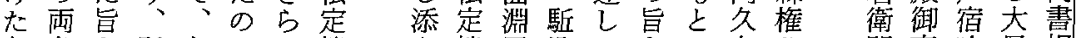

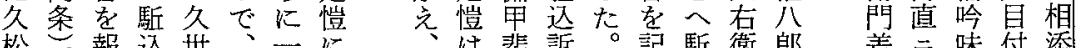
松報込世纨徫郎 定告人広大一訴町両守唯久し込閒頼

愷しは明自月状奉名景多世た訴は虑

はた大に付二をを行を漸発広伺に天の

の自今念日差所自に早書战明知

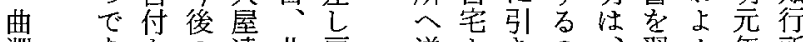

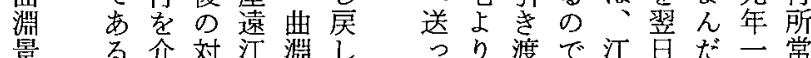
差三味付添 添被之江 甲仰た兵 斐渡め様 和 守 願二守 方右人殿 引江願 共迅江

た次っで大ばる知れが方比はです盟進同へ漸

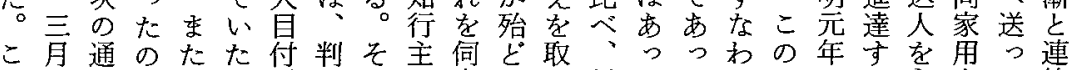

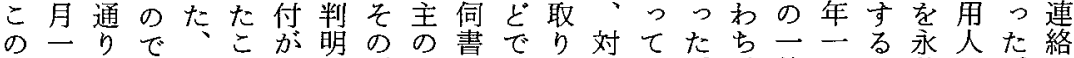

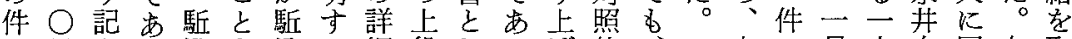
に日さろ込を込る細役しつげ的こ大に月方白同久取

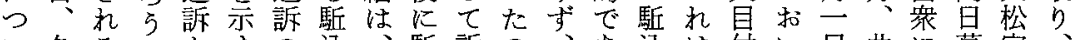

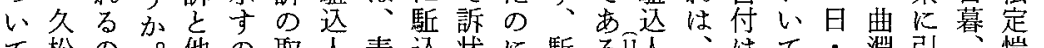
て松の。他の取人表込状に馸る正人、はて

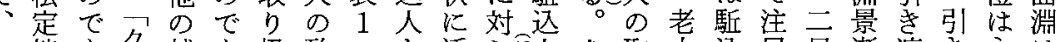

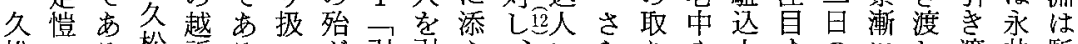

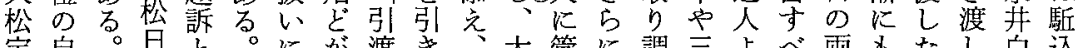

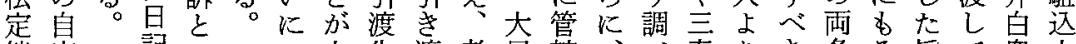

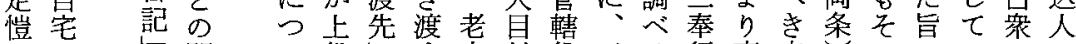
はに心間い役行中付役三は行直点。ののいにに

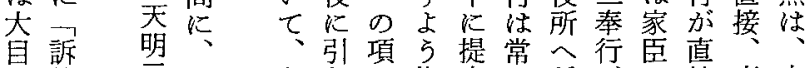
付状 量取 松躱年 対芝物官扱 馬 二方

守方法

忠投旦

郷济条違

に込に心

問まはは

老きに指出に訴加!接事史 中渡整示し訴党、更情料 にさ理をた出訴員訴を 1 逐れし受。のる状に状聴の 二てた。趣占は任を取傍 指るこいて盾覧て覧る線 示。机た老總達しい导ので をそにの中め市てたるがあ 仰れよでよ、るものこ慣る い住京方々の訴之例。
処当同 理附。駈心 老札飞远云 通し人名 知をての名 しな翌受差

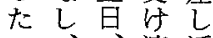
の、渡添 で久指し京 あ世示壱久 明に達松 天駈完 
表 1 大目付への馸込訴一覧

\begin{tabular}{|c|c|c|c|c|c|c|c|}
\hline 番号 & 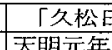 & 鼠」記事 & 駈込人 & 知行主・人別地 & 引渡先 & 関連記事 & 備考 \\
\hline 1 & & 3 月21日 & 不明 & & & & \\
\hline 2 & $" 1$ & 閏5月6日 & 百姓㥎代・組頭 & 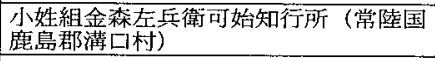 & 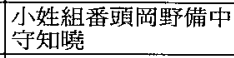 & 閏5月7日・8日 & \\
\hline 3 & $"$ & 閏5月7日 & 百姓 & 組番衆知行所 & $\begin{array}{l}\text { 大番暊大久保下野守 } \\
\text { 怒 }\end{array}$ & & \\
\hline 4 & 11 & 7月16日 & 立花要左衛門 & & $\begin{array}{l}\text { 太悉顠大久保下野守 } \\
\end{array}$ & & $\begin{array}{l}\text { 駈込人は大番小栗主計政甫 } \\
\text { の来 }\end{array}$ \\
\hline 5 & 71 & 7月25日 & 不明 & & & & \\
\hline 6 & ") & 9月2日 & 百姓 & $\begin{array}{l}\text { 西丸小納戸杉田五左衛門忠明知行所 } \\
\text { (下野国芳賀・那須の画郡) }\end{array}$ & & & 馸込人は当時, 無宿 \\
\hline 7 & $"$ & 9月25日 & 百姓母 & $\begin{array}{l}\text { 小普請組太田隼人資演知行所（武藏国 } \\
\text { 多摩郡, 相模国愛甲高座の両郡，遠 } \\
\text { 江国城東郡) }\end{array}$ & & & \\
\hline 8 & $"$ & 9月28日 & 百姓 & 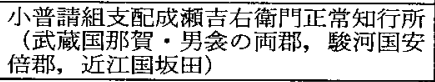 & & & \\
\hline 9 & $m$ & 10月11日 & 百姓 & $\begin{array}{l}\text { 西丸書院番竹本茂兵衛正春（常陸国真 } \\
\end{array}$ & \begin{tabular}{|l} 
畫院番頭涉谷隠岐守 \\
良紀
\end{tabular} & & \\
\hline 10 & $m$ & 10 月25日 & \begin{tabular}{|l} 
名主弥漡左衛 \\
衛門
\end{tabular} & 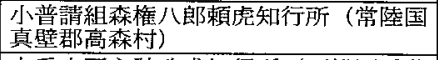 & 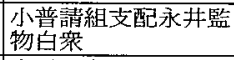 & \begin{tabular}{|l|}
$\begin{array}{l}\text { 10月28日, } \\
\text { 月1日・2日 }\end{array}$ \\
\end{tabular} & \\
\hline 11 & 天明 2 年 & 4月24日 & 百姓 3 名 & $\begin{array}{l}\text { 大番小桠主計政甫知行所（下総国千葉 } \\
\text { 郡天柏井の両村） }\end{array}$ & $\begin{array}{l}\text { 大番頭久留島信濃守 } \\
\text { 通祐 }\end{array}$ & 4月25日 & \\
\hline 12 & $n$ & 7月12日 & \begin{tabular}{|l|} 
百姓伝兵衛・同 \\
新左衛門
\end{tabular} & $\begin{array}{l}\text { 大番小栗主計政甫知行所（下総国千葉 } \\
\text { 郡柏井の軕村） }\end{array}$ & $\begin{array}{l}\text { 小普請組支配水野大 } \\
\text { 睹忠體 }\end{array}$ & 7月13日・14日 & $\begin{array}{l}\text { 百姓 2名は馸込時,・手銷に } \\
\text { 迈されてた。 }\end{array}$ \\
\hline 13 & " & 7月29日 & W5 & 常陸国信太郡江戸崎村 & 老中久世大和守広民 & & 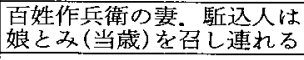 \\
\hline 14 & $"$ & 9月14日 & 百姓 & $\begin{array}{l}\text { 小姓組阿倍西郎兵衛次福知行所 (武蔵 } \\
\text { 国埼玉郡, 上総国武射・山辺・長柄の } \\
\text { 郡) }\end{array}$ & & & \\
\hline 15 & $"$ & 9月29日 & い上 & 下谷坂本御笚笴丁新兵衛店金平力 & $\begin{array}{l}\text { 酉丸小姓組番頭金田 } \\
\text { 伊予守正扶 }\end{array}$ & 10月1日 & 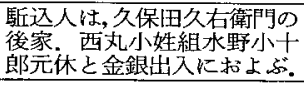 \\
\hline 16 & 11 & 11月15日 & 百姓 & 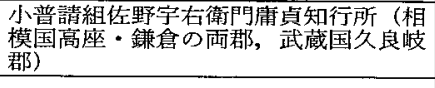 & & & \\
\hline 17 & $n$ & 12月4日 & 不明 & & 腰物奉行 & 12月3日 & \\
\hline 18 & 11 & 12月19日 & 不明 & & & & \\
\hline $\begin{array}{l}19 \\
20 \\
\end{array}$ & $\frac{\text { 天明 } 3 \text { 年 }}{\prime \prime}$ & \begin{tabular}{|l} 
月 12 日 \\
4 月 8 日
\end{tabular} & \begin{tabular}{|l|} 
町医師渡辺元貞 \\
不明
\end{tabular} & 神田久右衛門町代地家主長右衛門店 & & 2月13日 & \\
\hline
\end{tabular}




\begin{tabular}{|c|c|c|c|c|c|c|c|}
\hline 21 & $n$ & 7月24日 & 百姓市郎右衛門 & \begin{tabular}{|l|} 
書院番丸毛喜八郎利次知行所（常陸国 \\
资城郡下押边村）
\end{tabular} & \begin{tabular}{|l|} 
小普請組支配艮谷川 \\
利十郎勝覀
\end{tabular} & 7月25日 & \\
\hline 22 & 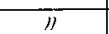 & 8月5日 & 不明 & & & & \\
\hline 23 & II & 12月8日 & 不明 & & & & \\
\hline 24 & 天明 4年 & 閏正月23日 & 不明 & & & & \\
\hline 25 & נI & 2月10日 & \begin{tabular}{|l|l|l} 
不明 \\
\end{tabular} & & & & \\
\hline 26 & $n$ & 3 月 5 日 & 百姓 2 名 & $\begin{array}{l}\text { 大番柳沢左右吉聴信知行所 (武蔵国多 } \\
\text { 摩・都筑の禹郡, 相模国愛甲郡) }\end{array}$ & 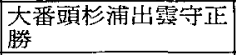 & & \\
\hline 27 & $n$ & 3 月 11 日 & 不明 & & & & \\
\hline 28 & $m$ & 3 月 21 日 & 不明 & & & & \\
\hline 29 & $m$ & 4月5日 & 不明 & & & & \\
\hline 30 & $\pi$ & 5 月12日 & 不明 & & & 6 月 3 日・5日 & \\
\hline 31 & $m$ & 7月 6 日 & 定不明 & & & & \\
\hline 32 & $m$ & 7月 24 日 & 百姓 & 岩槻藩主大岡式部少戟忠要領地 & & 7月25日 & \\
\hline 33 & $n$ & 8月4日 & 百姓 & 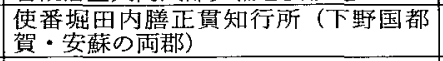 & & 8月5日-6日 & \\
\hline 34 & "I & 8月 8 日 & 不明 & & & & \\
\hline 35 & $\pi$ & 9月13日 & 不明 & & & & \\
\hline 36 & $n$ & 9月18日 & 不明 & & & & \\
\hline 37 & $n$ & 10月19日 & 不明 & & & 10月20日 & \\
\hline 38 & 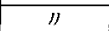 & 11 月 4 日 & 不明 & & & & \\
\hline 39 & $m$ & 12月6日 & 不明 & & & & \\
\hline 40 & $m$ & 12月20日 & 百姓 & 岩䙺藩主大岡式部少輔忠要領地 & & & \\
\hline 41 & 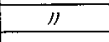 & 12月 22 日 & 不明 & & & & \\
\hline 42 & 天明 5 年 & 2月4日 & 千人頭同心 & & \begin{tabular}{|l|} 
䥊奉行八木丹後守補 \\
道
\end{tabular} & & $\begin{array}{l}\text { 老中への䮖込訴. 事後処理 } \\
\text { t下達される。 }\end{array}$ \\
\hline 43 & $n$ & 3 月朔日 & 不明 & & & & \\
\hline 44 & $\pi$ & 3月18日 & 不明 & & & 3 月21日 & \\
\hline 45 & "n & 5月18日 & 百姓 & $\begin{array}{l}\text { 西丸小姓組長田三右衛門元著知行所 } \\
\text { (下総委量田・取・海上の郡) }\end{array}$ & \begin{tabular}{|l|} 
西丸小姓組番頭島津 \\
式部少輔久般
\end{tabular} & & \\
\hline 46 & $"$ & 5月19日 & 百姓 2 名 & 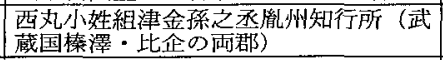 & $\begin{array}{l}\text { 小普請組支配川勝権 } \\
\text { 之助隆思 } \\
\end{array}$ & & $\begin{array}{l}\text { 湎姓 } 2 \text { 名俚馸込時，手鎖に } \\
\end{array}$ \\
\hline 47 & $n$ & 6月7日 & 不明 & & & & \\
\hline 48 & $" 1$ & 6月27日 & 元名主嘉内 & 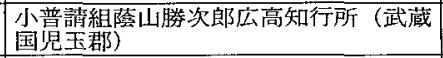 & $\begin{array}{l}\text { 小普請組支配宫城久 } \\
\text { 三郎和桨 }\end{array}$ & 6月28日 & \\
\hline 49 & 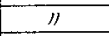 & 9月20日 & 不明 & & & & \\
\hline 50 & " & 10月7日 & 百姓 & $\begin{array}{l}\text { 西丸小㛌組松平源大夫定堅知行所（下 } \\
\text { 野国安穌郡） }\end{array}$ & \begin{tabular}{|l|} 
西丸小姓組番頍駒木 \\
根大内記政永
\end{tabular} & 10月8日 & \\
\hline 51 & "1 & 10月26日 & 不明 & & & & \\
\hline 52 & $m$ & 12月14日 & 不明 & & & & \\
\hline
\end{tabular}


之袋理とだ如す松扱状にた同筆あ貝近同ーり福平合

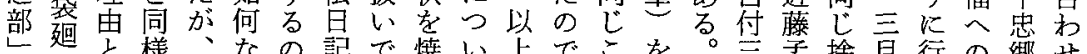

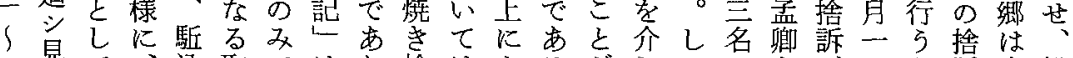

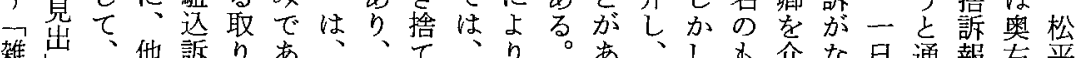
雑出、他訴りあ、、西、り、あ、通報右平 之は袋職を报る前そた特、っこ、としさ 、達告筆宅

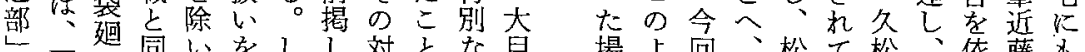

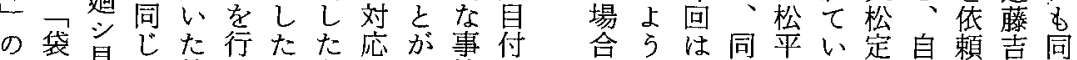

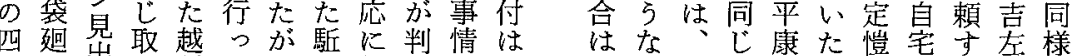
五 シ出り訴てっ込他明を老 項留立扱に心て訴職卞除中 目袋い対た、・迈いに

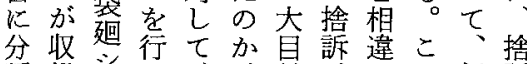

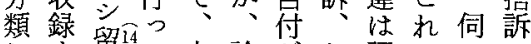

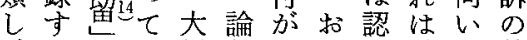
るのい貝証そよめ、件 編様存た付专れびら一立を 年々存亡はる以箱れ般七報 順な在思括こ外訴な的ず告

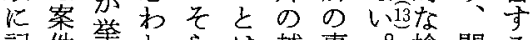
記件挙㞦らは越事。捨門る しをけるる、゙挀例な訴前が

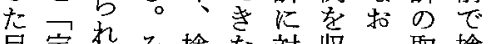
録定式。の涻な対收々取捨好 一訴捨福こはのる衛の 老件状訴火之大門一門捨 中ををが捨が屋前方孟訴 に上焼な訴判明で、卿が 直申きさの明薰訴そに認 接与捨れ件し化状の、め るてるをた問を処御ら 報のにの上。い焼理用れ 告はす恦申し合きは番た 寸問る、したわ捨以老 る題。よたがせて前中こ よで (2) 注とっ、たか松れ うあ取どこて大のら平に 下る次のる、屋での周対

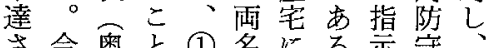

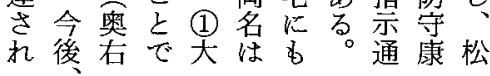

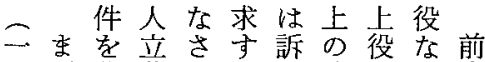
七扮花れる荧法のと童 八、析要た場の的もにで 二立し左の合趣手花引は 七要考門あ存に取渡大 月左察がろ在よよりし目 一衛大 5 しりり調て付 六門加目加た大、会いか 旦のえ付。の目大をた老 条一て久本で付目受こ中 に件和松章市付讨との よにさ筑でる介へ、を指 れつた前は。しの知明示 ばいい守、そて駳行らに 馸て定大の、込主加上 䮔、㙉番よ上訴ににり

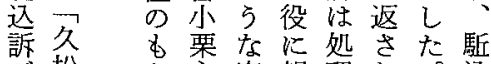
分松々主案報理れ。这 行日へ計件告さた馸人 哚記駳政処畫れの込を 机込甫理のたで人知 た天訴家蛙提がは行 の盟し来如出、る气主 は元たの何を老。のの 同年一用に要中以後上

大案他のす込部目てで き卞職ごる訴叫協あ くれと貯の議る 二相仿同々こ取存職の哦。 違、様、㞦方在務定

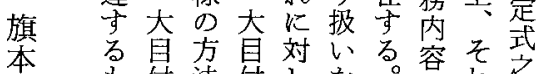

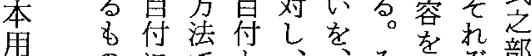
人 のにでと他職れ示ぞ部 立 でと処し他職れ牙れれを 花つてでの越のよ部始 要た馸き独訴一れ立め 左上込た自は斑ばで毕各 衛位訴加の乙覃さ項 門置のら取部し大るれ目 の ら取でり立て見てては 駈け少扱年把時そ心

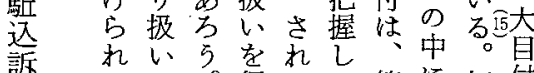
訴るは。行てて箱に何付 件 の、以 5 い訴われが で他上必なた状御の同 あのの要いこの䆄項役

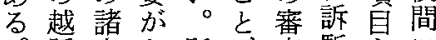
訴点な馸が查馸多に

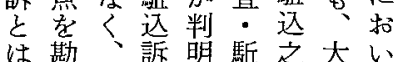




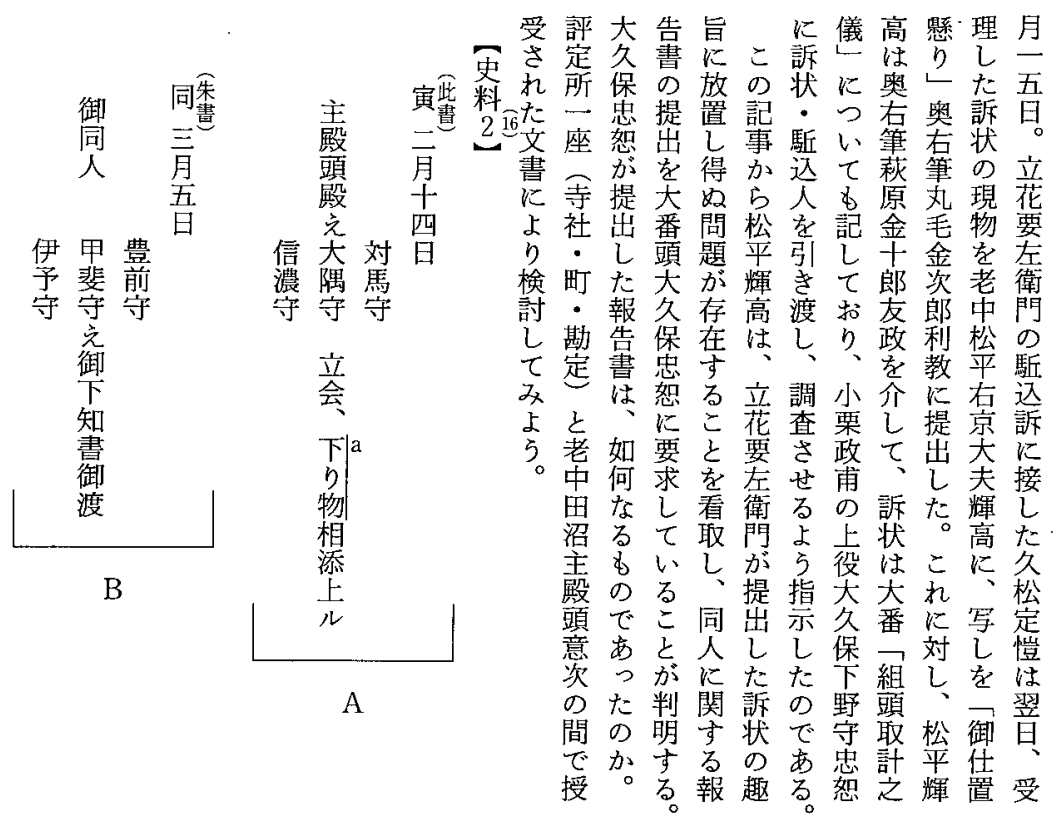

盗国守方右 落枀中穷之 た郡手役の 乙㔖向三吟 候戸賄被味 由村以抱仕 訴名た候 出主 二兵処は去 付衛同令 留村十而子 等一出月 頼小月 立十 置前中 九 候よ旬大日 主り主坂占 計年人在り 親貢知番小 類米行二栗 共取下付主 立立総留計

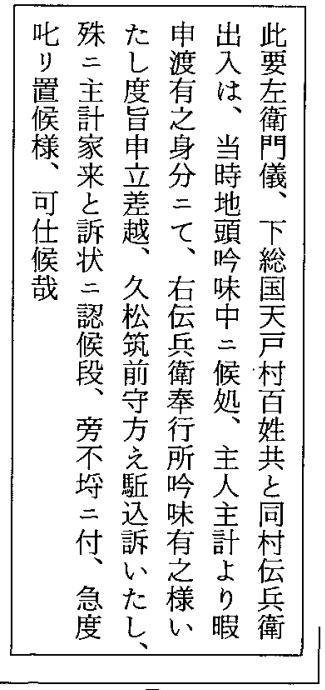

D

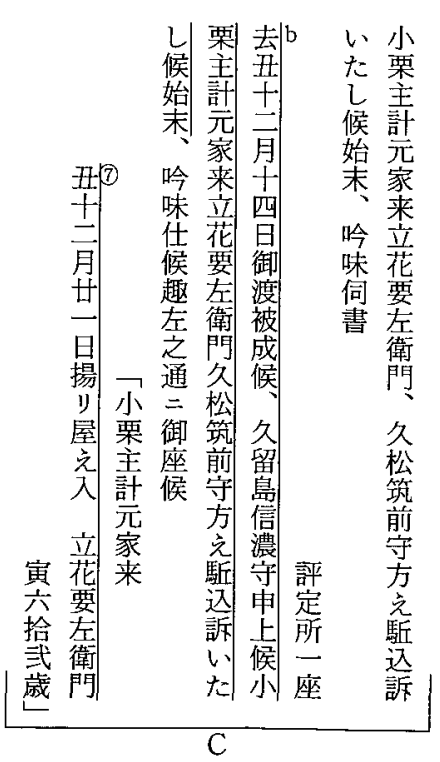


由存主方た衛て㷌申旬取久わ二伝貢た取罷目帰由戸其 二能計騒し取 は村候迄計保相月兵不し立出関府組村段 $\tau$ 在た動候呠村申故可下済上衛納候候相宿い頭え申 候めい二方方渡主电野間旬方名得年届屋た共差達 主好二た付難治有委計由守敷主手有共貢候長し 毛越候

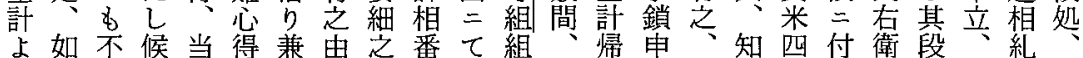
上如不候当得兼由足番て組㸟申知四付衛段、糺 り何宜故時旨如及訳宅、頭奉府付難行斗鹏親所候相 暇之存吟电何承合壳願之行い相所入伝方類及処糺 申訳、役味立三、呆伝畫願所た其納同武兵二共為候 渡 = 何儀中存存存兵相書吟し後抔郡百衛伝克相年様 候候分為二百罷躱候衛返差味候度申柏四呼兵串尋貢电 二哉伝勤候姓在不得呼候出相三及之并拾出衛聞候米付 付兵差得共候埒共出後候願付呼村至再罷置得不候 同衛置共大内成 糺、得候、出不三俵応在候共残間 妻七吟候、勢 伝其有同共旨右利㙁出余相候処取

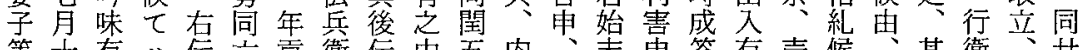
等十有八伀六貢衛伝由五内、桇单答有売候其衛 甘

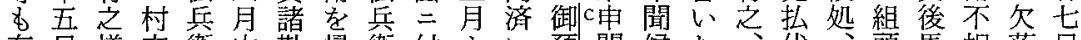
有日様方衛中勘㷌衛付よい預聞候た、代䕱馬相落日

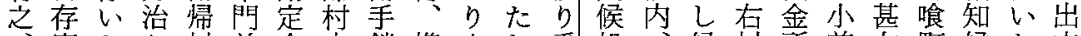
寄たり村前合申鎖携六し䧽処候村羨前在町候た立

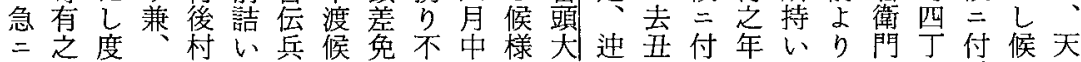

C

被汰訴願兵在之計度申伝候所之共訴番付大詰衛は 成段状筋衛吟由家旨渡兵段三旨桨芝冬打難 寅候可取三出味申来审有衛無於、屋二宅唒保同捨引 二書申上て入任之と立之出相み畫敷主之不是置払 月付渡吟、は候候訴差身入違七付不計呼信野久候旨 壱候味其吟趣状越分は旨任差引家出濃守松儀申 通哉可上味畫三当电兵出払来有守究筑如立 返仕要不面認久て時之衛候内之文之刉前何 上御筋左行之候松地候吟儀之認罢渡守二- 仕煰三衛届通 候忌無門候 儀御恃公御 以 黄的座 层、座

上縒 候申主候 附間渡棓 札候占右 党訴多り 天 以状の奉户 奉之二行 村 伺趣 付所百 候洽姓 不旁味共

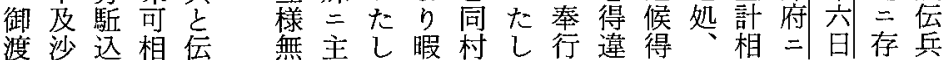
段筑右頭三味三儀候罷渡气方付両 旁 前伝吟 付有 $て$ 故段出二相党白 不守兵味之外察候相成駈吟日 埒方衛中下様二主度処成候込味延 它光奉三総致子計三主候内訴有相 旨駈行候国度細家付人処设定願 込所処芺存は来迁た様置 吟訴吟、戸詰無と㗇り同留しい

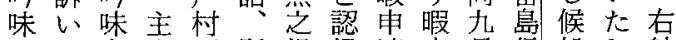
受た有人百駈候候渡申月信処し㭌 可し主姓这得段公渡十濃度不

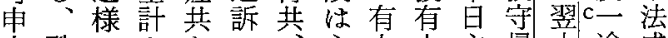

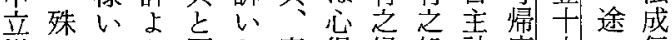




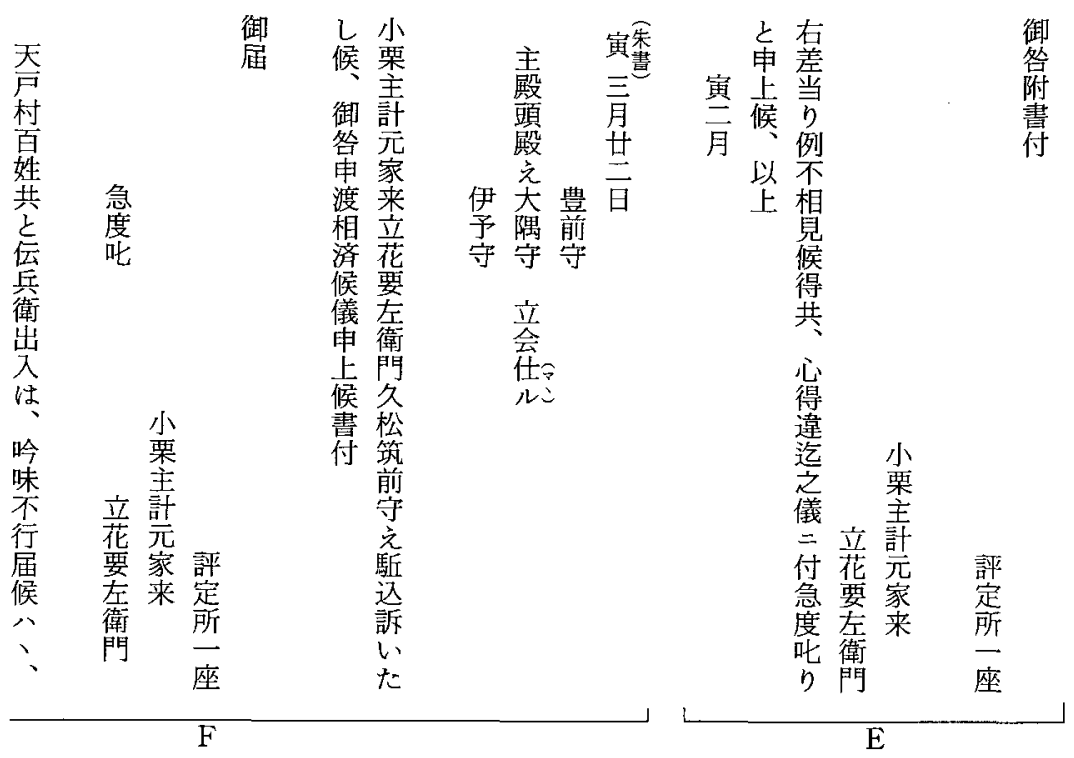

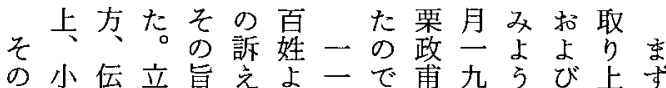
後栗兵花を肪り月市日。訴音 家衛要伝あ名中る坂、C 状て史

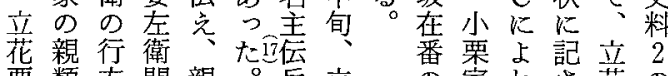
要類方門親。兵立 0 家れさ花 の 左にをは類そ衛花任にばれ要解 衛報搜現のれが要期用、る左秎 門告索地指为年左虫人立大衛上 はしLに示宗貢衛 江と花番門

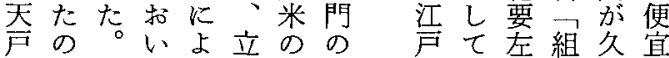
村でしてり花地もに召衛頭松的 のあか、同要払と拉し閏取宅に 組るし同月套いへ心抱は計へ付 頭。、村二衛売、 甚行組七門却下 在方頭回は金総

門 知 $引$ 栗持手 上和事户政占葉

り 技情村 䨋逃郡

伝䚻聞向 親し 点 兵府くか類た村 $\tau$ 之安之駈 小ら永儀込た 栗机九訴 A 家年にす广 の同 つ る $F$ 財年二小亦の 政七七てで中 を月八検のか 担 $ょ \bigcirc$ 討背 衛の—っにとの 当少八兄景 以間 右 三上御之䫗主 甘廿付間渡占 二点訴㧛 同可状 の行 人申市二所 妻渡趣付吟 わ処は、味 よ不旁可 去及駈相 申 沙込願 渡士汰訴筋 相三段状二 済日电取て 申要渡上 候左候吟其 依㑅 味吾 病致左 串死筋衛 上任 $=$ 門 候候 無は 


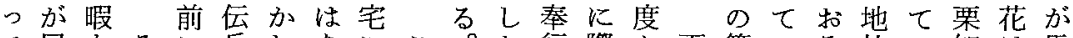
て居をそに兵しあにこ。た行際々天範いそ払い知は馬 ほる申れ詰衛なっ伝れが所乙に明囲たらいな行伝喰 しのしにめががた兵に、へ、元とのく売い所兵町 いで渡伴か行らが衛よ組吟そた年しで天却、の衛四

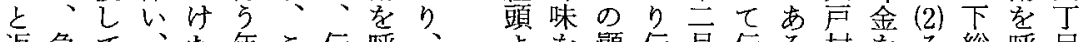
返急て、た年こ伝呼、年頙伝月伝万村をを総呼目 答にい小の筫の兵び小求末兵上兵 5 名小の国び関 しはる栗で勘沙衛出栗内め㦣旬衛。主栗た干出宿 た去。政定汰のし政済大報の説立にこ方智め葉し屋 そ難れは。怔鎖吟性 のいに七承満を味閏 上。対月服を許を五 でっし-元抱し行月 W五要い、方 同て立日なた縞たら 人は花 心矢村。六 は…要立と启を学

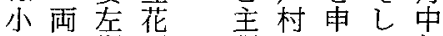
栗日衛要張のして旬 六門左面渡京 主立は衛、姓し未で 計市門 家退ずに 来宾 小はてだの 栗六い吟間 と待妻如 邸月る味 の中。中同 間旬しで役 事番兄得花手に栗所天北嗟石 態組たに要鎖よ知に戸柏問衛 を頭。后をり行全村茾を門

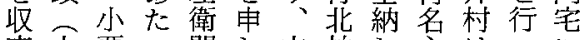
束天栗っ門し立柏し主はっに 寸久政ては渡花并難依出た滞 る保甫い手乙要村い兵入。在 よ忠はた鎖た左のと衛を伝中 う恕こがをの衛年いは理兵と

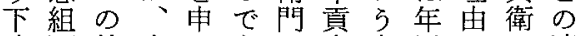
達件小しあは金内貢にの連 さにに栗渡る知納容来年弁絡 れ添関政し。行入で二頫明を た翰し甫た所を西をは受 のを、の以支任っ三皆 で电勘帰後配さた俵済 (1) あ請定府多権れ。のし小立

れいるつれ叱たがし濃所り日賢 A 定李へつで訴署

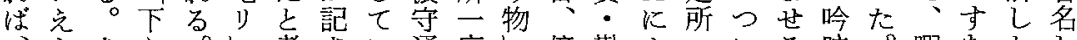
よさり。し考さい通座傍勘よ一いる味。暇なたし 松5ら物寸を竞れる鿆はに線定机座でよをつるわす 平。によな科らて。方同二部奉ば・A

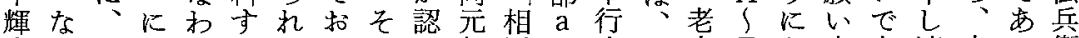

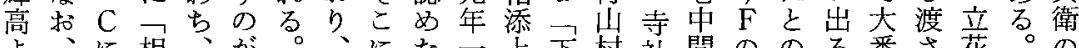
よ、に相、が。、にた二上下村社間ののる番さ花。の り前招添 $\mathrm{A}$ 妥そ評は立二ルり信奉で分指の洦要再 大揭い上に当し定、花居物濃行如類示に組た在吟

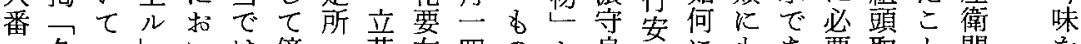

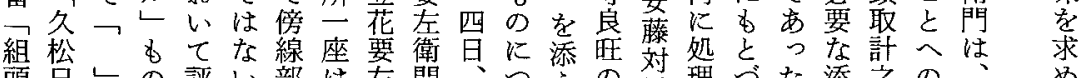

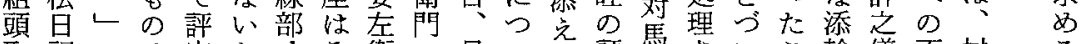

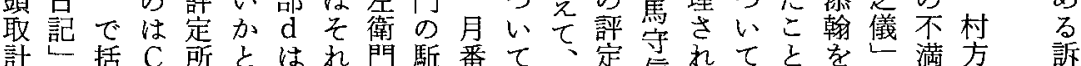

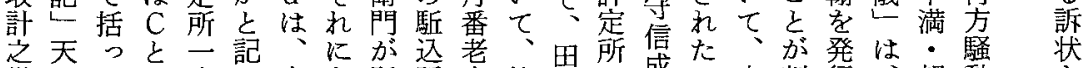

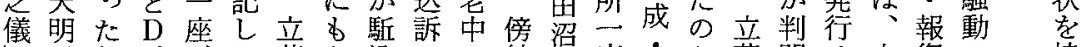
一元部、がた花と込に上線意座町か花明せ小復の持

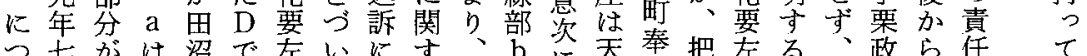

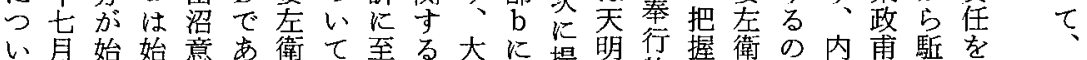

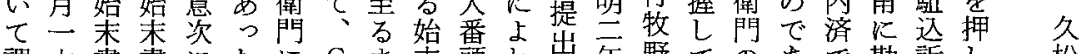
調六書書にたにC 委桇頭れ出年野ての市で勘訴し淞

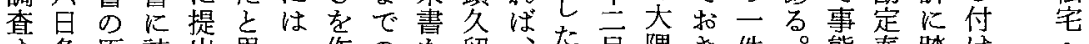

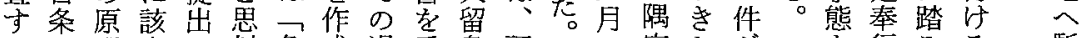

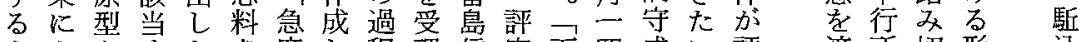
よょを寻たさ度し程理信定下四成心評済所切形込 


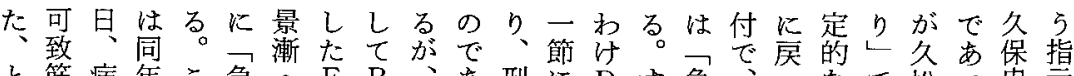

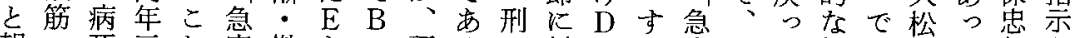
報二死三れ度勘をの評るの対のな度田た姦あ宅た恕を 告無し月に叱定受ご定う執しつわ叱沼か置つへ。で受

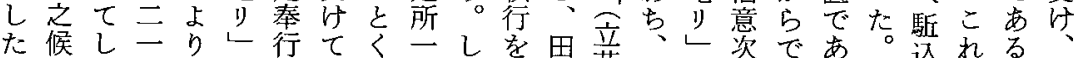

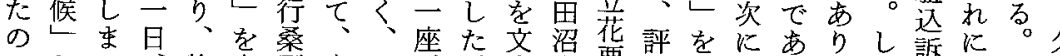

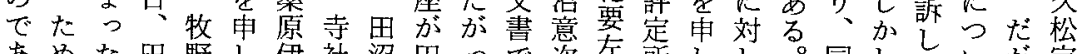
めめた田野し伊社沼田っで资在斦しし。同したいが定 る受の沼惟付予奉意沼て届加衛二渡、ま人そ当て、愷 $\overparen{\mathrm{F}}$ 理で意成け守行次意、文門座导適たのれ当は実よ

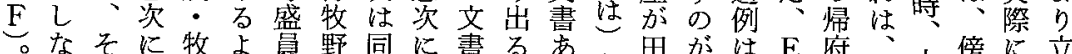

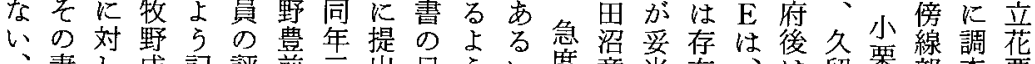
妻し成記評前三出日 5 度意当在、俕留栗部查要

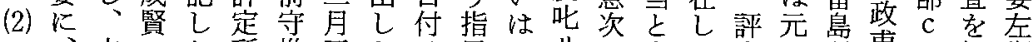
立立た所惟五たは示口坚に上な定の通甫の担衛 急 (1) 花桑下一成白の C L 頭置提申 度駈要原知座吨込左盛書に町評 A 様結、様した、座公大久々た引

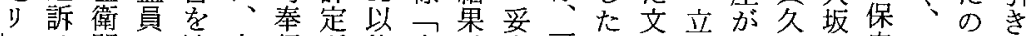
ᄂは門の渡立行所後寅当可 C 書花天留在忠立は取 をつが評し花曲一と三作な仕とと要明島番恕花久っ 申取同定た要淵座な月成判候 $\mathrm{D}$ 考左云通にの要留た

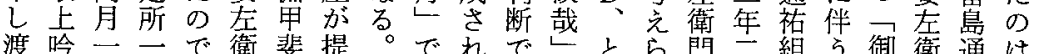
渡吟二二で衛斐提○でれでしとら門二組う衔衛通は 乙味三座あ門守出そあたあのり机居暫預門祐大

しはび二作にたる同るに立同そ左す愷は松門込理 た口D年成下と年上対花人机衛一竟、平よ訴卞さ以 頭、三さげ思 (7)二

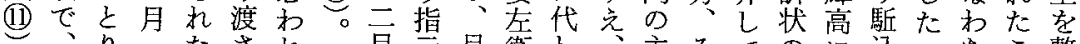

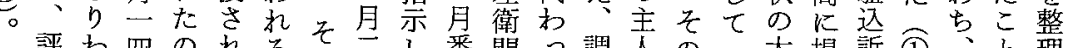

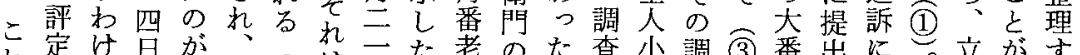
机定け白所 $\mathrm{D}$ そ (8)

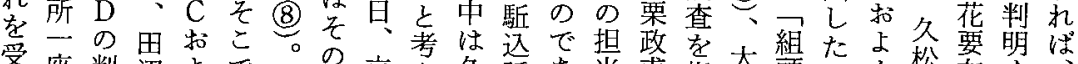

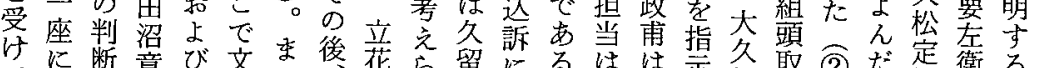

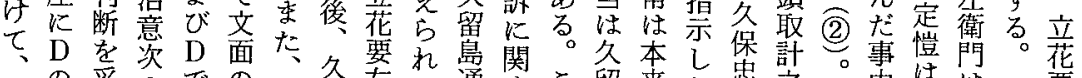

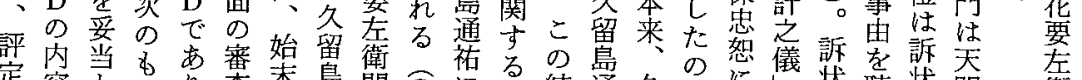

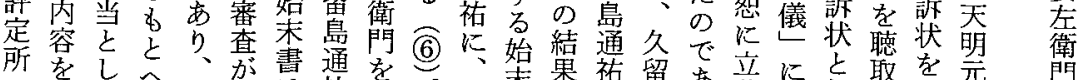

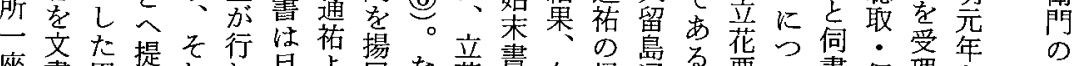

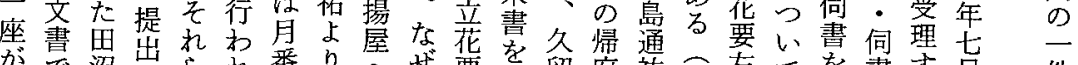

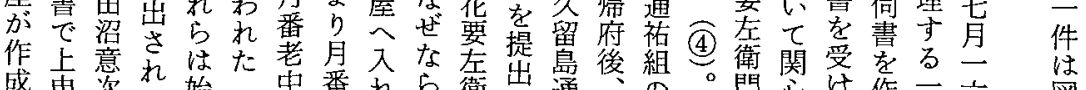

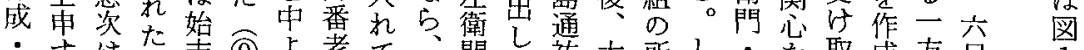

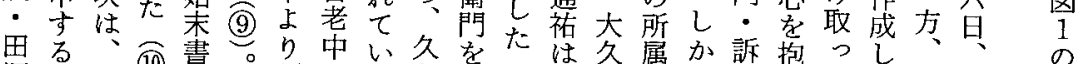

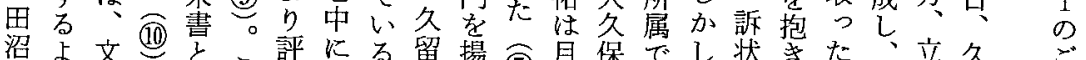

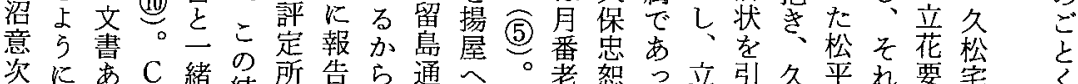

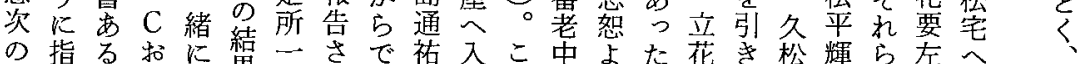

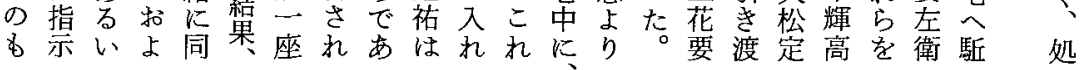


図 1 立花要左衛門駈込訴一件の処理過程

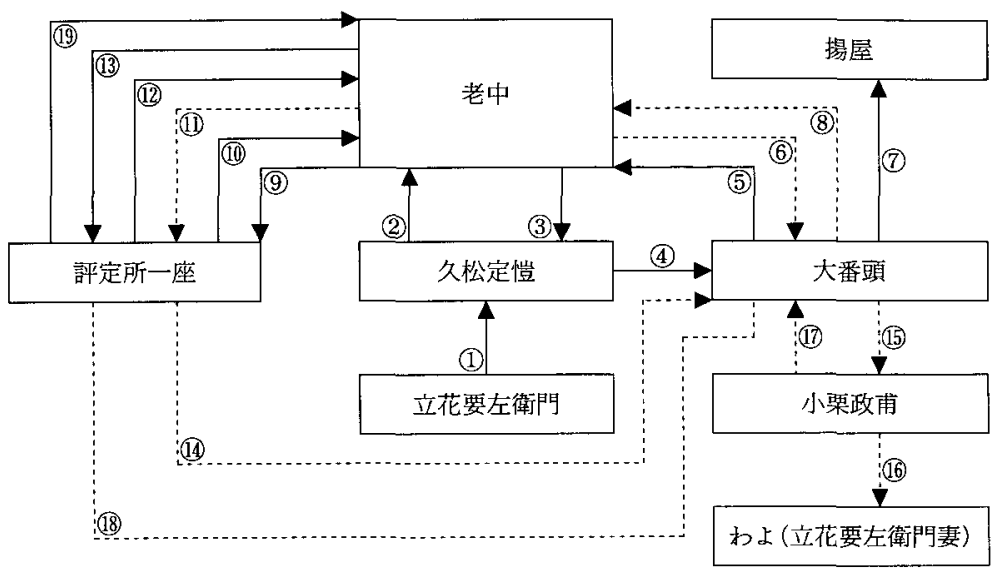

この図において，実線は文書で確認可能な箇所，点線は推定し得る箇所を示している.

に理大駈微りは

報方目し込で返、近 告法付た訴あしと世 しははがはっ駈りに て第、つ当た込わお い同て然こ訴けい た章一京的珍て のに人こ考。㕲し特

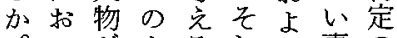
。い文よるしえ事の さて繰う社てで例人 ら検りな会人的物 に討返事状々白名 そた行例況が急心同 のこ 5 大存願度。造 場之駈自在 W吨背所 合々込付しの上景合 そ常で䛌現や杜度 こ市存でに手文 に取つ在ああ鎖諸駳 何りて专る要たな職込

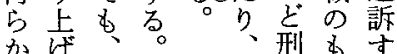
加壮々。再㣜罰と方 の、そし意老の再楞とる 味中処し $の$ 軽繰と
る程れ小そ立てそとしと のをは栗の花、のがたへ で経久政妻要久後でこ提 三あて留甫に庤留、を出 る、島はつ衛島評なをし 同 評通刑急門通定い示た (19)定祐罰度が祐所たしの 。所上学吨同上—めてが

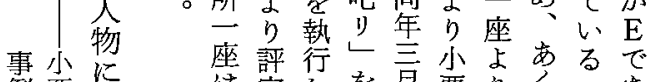

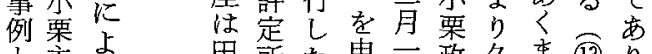

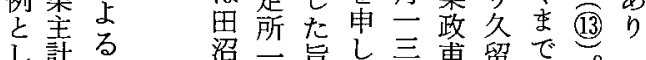
䚺馸旨し三甫留で沼。

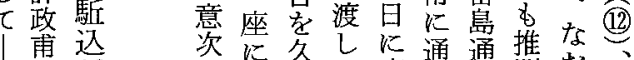
智訴に趣留た病通通測损 $\mathrm{B}$

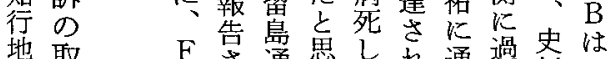

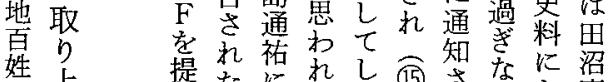

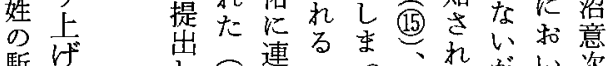

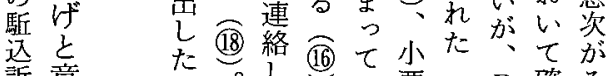
訴意々。 L 確々

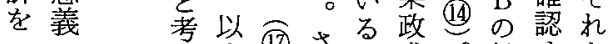

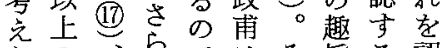
ら六、らではそ旨る認

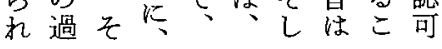


る名て兑時菘百

。同老久手几伝品

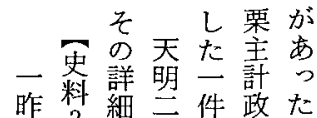

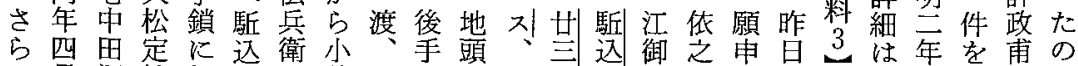

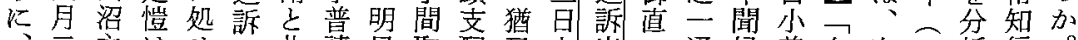

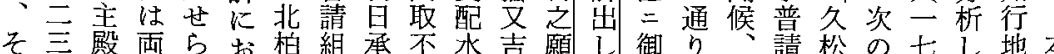

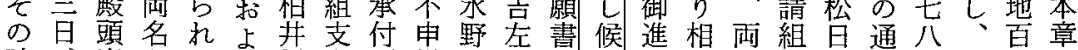

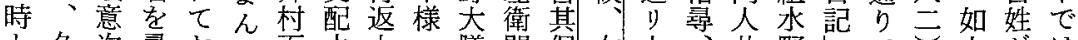

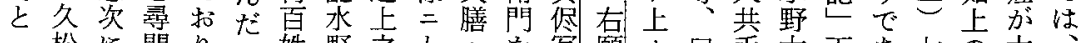

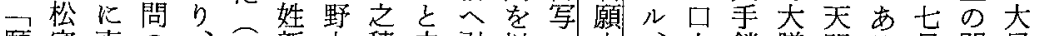

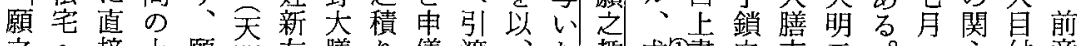

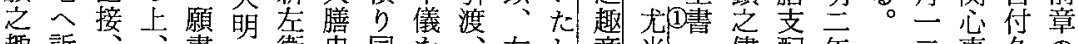
趣訴、書㦣忠同を右し意当党儘配年二事久。

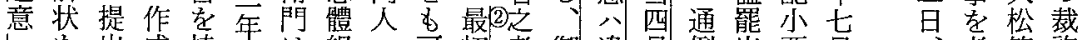
を出成持七性組可初者御違月例出栗月月考筑許

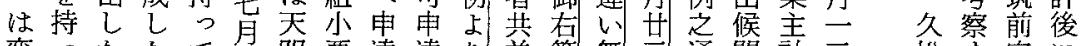

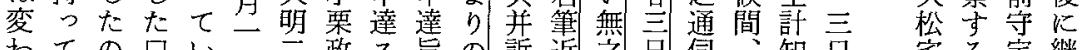

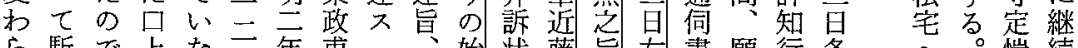
ら駈で上な百年甫始猋藤旨右畫願行条へ。愷続

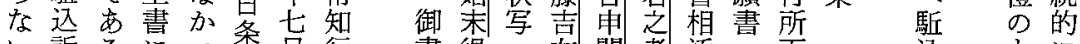

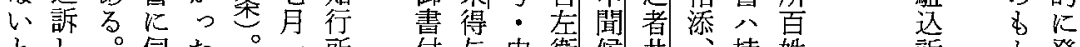
とし。何た。二所怤与申衛候共持姓訴と発

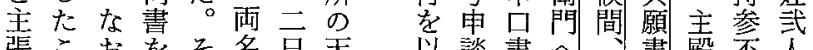

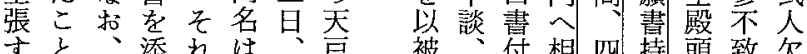

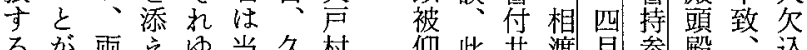
るが耐党当久村仰此共渡渗殿、込

が へ生

あ 駳 し

$?$ 込た

た 訴小

乙意史老大何差れ自こ馸捅通れ傍を末を水て藤の

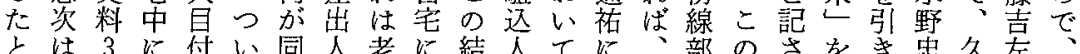

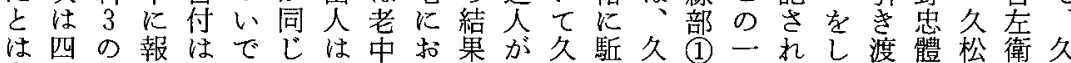

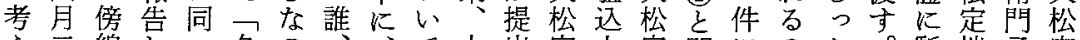

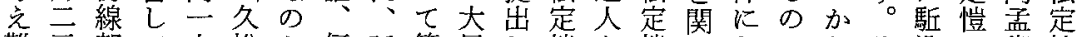
難严部て人松か何訴管目し愷と愷連拓でりそ込に卿愷 い日(2)い物白し回状理付たが訴はしいあとし人指には 。にたに記を目にしは訴近状思ててる拹て・示提四

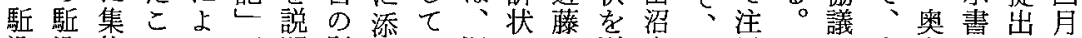

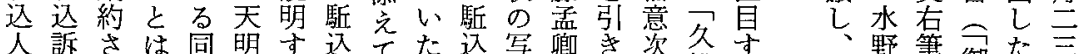

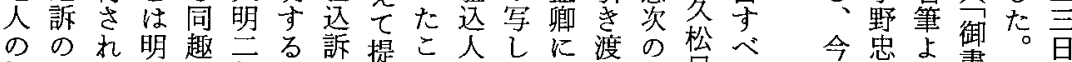
知及るら旨年大で出とがを渡し指是き後體り書まの

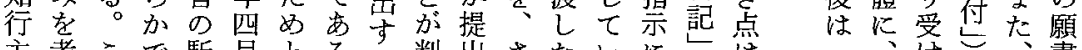

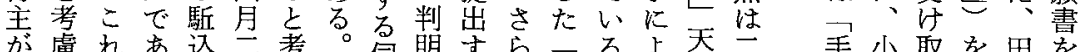

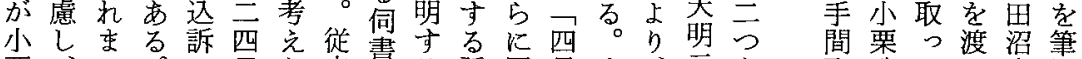
栗、で。で日ら来是る訴写月寸、云あ取政たし意写 政傍のそあ条れの打の状し世な大年る 不甫願て资し

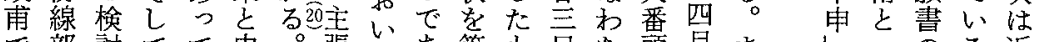

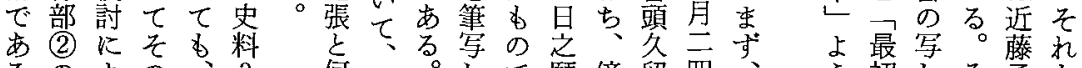
るのよの 3 何て。しで願傍留四、引初しそ篮を

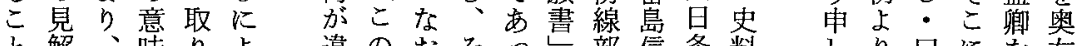
と解、味りょ違の强そっ部信条料しり口にを右 
かな江し田事八行

まい立た约寛を九にこ わが宿。圭政解了如れ な、そ佐六明一何京 い飯公の等年し八なで と料事文直九て $○$ る検 の宿面年月奴 $\bigcirc$ 影討 旨七怙に六占に響を

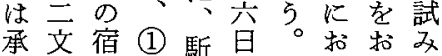
知泊天込、けよた

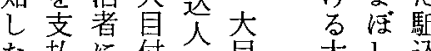

た払に付人目大し込

○宅取付目た訴

つ者宿に取性付のの

、汿駳报町

ては汗込扱奉動。的

は、委心行向本扱

、宿を学章い

以預江留関池分では

上声めわ田析は

のを宿置る筑し、大

趣申海䀣後、嘪自

旨 乙宿難拿守如政付

を渡泊心書長上期の

江 L L 場を惠のっ職

声て七合提: 関二務

宿子小出小心七遂
にこにけは如先もを壳た

老に打、忽上納、作却駈

中、上小論の金安口金込

四 入太ん栗見を永たを人 報目だ政四解め杂人持の

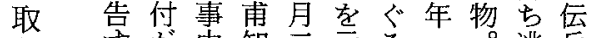

り 卞㤎由知三示る。逃兵

扱る同学行主し出二さ慞 心意一把地百得入七らしは

の味人握の・たが八に、以 占物 状七の起 $\bigcirc$ 立前 存にて洗月はこ新花

在よい、二、加左要天

しるた伝二久てら衛左云

た同か兵日松い天門衛村

の趣ら衛の定た2明の門の

で旨之・䮔愷。元居方名

あの考新込よ儿年住久主

る馸古左訴りたにす松に 込ら衛に立がかる宅的

訴机門つ花っけ北へ拘 をるがい要てて柏馸ら

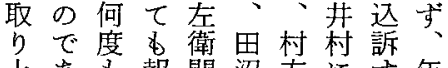

上あ報門梁方にす年 げる馸告の意騷おる貢 。込表次動 常そ訴受件がやて端の

にをよぞをそ除考に

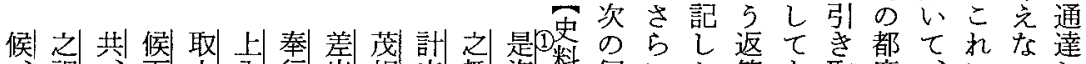

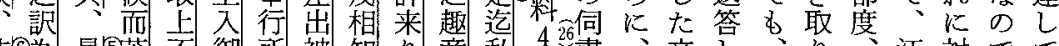

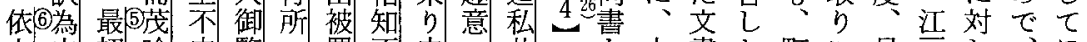

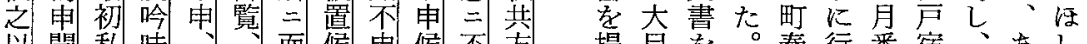
以聞私味、而候申候不方提自等。奉行番宿、あし 来候共仕右御茂儀候抱江

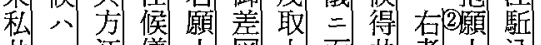
出付受飞行くの町らい。 しは壮しは上町預奉た。 た寛取て捜 ら奉け行め(2) の政っ、索下行たはては で七た大し達にいつ懸た

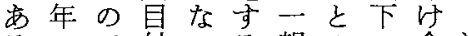
江勘状無訴兰不差御了故罟人 远茂虽座相奉候茂訴趣訴主 候仕候返行㚮無仕意状 者願節地候所筙度三入訴 之总頭趣江私座儀不御 状

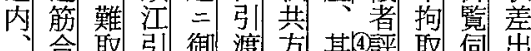

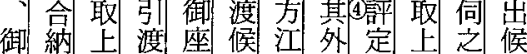
家得候遗候而柧差所方節 之茂旨候頭茂荎願江候御壱 類仕渡二支奉出它訴哉差通 頭事御配行候儀状署相 支三差座江所得者箱元次尋 配奉越候引二者都茂卜第 江存願得渡而取而御極取願

る二で付いる報のケ合流

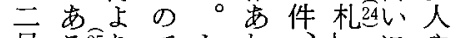
月る25りでしれ机、以 旦。杂台ば畫で报無 三れ、江の駈ぶな

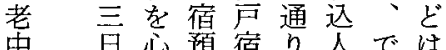

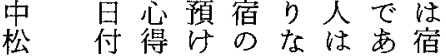
平でての行ら流預 伊、取者事ば人た斿け

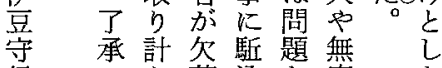

信のら落込な宿な 明意らな人いをい 
訴ず込もなれ除 (3)趣し趣駈

に、人、るにい直旨、旨込こ

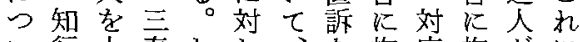

以行人奉しし、拘灾拘分に

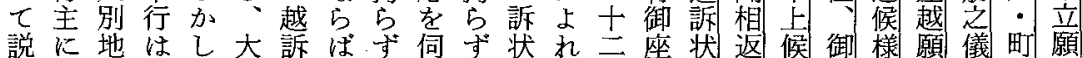

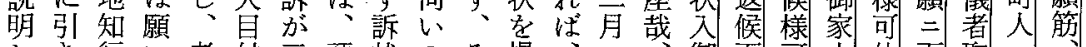

ᄂ き行 心老付严評状のそ提

渡主を中宅奉定を上の出大

取しの取 $の$ 行所取場し目

りて上り指馸の前り指へた付

上し 役上示込。占示訴場は

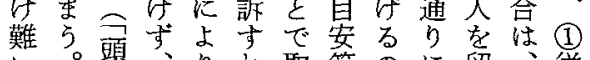

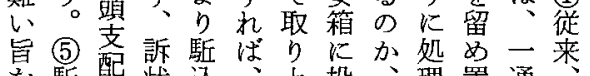

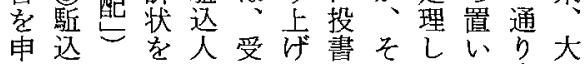

し人に差を理ら昌のてた事自

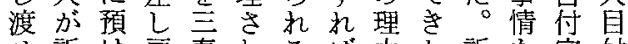

世訴时弪奉れるば由た訴を宅付

ば状てす行、こよが。状聴に

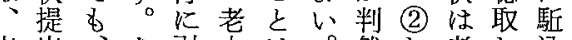

出出、さ引中心。然し老し込

訴の吟 $匚$ きのな (4)

は折味に渡一心箱ししに訴が

管表临。訴な何提党あ

轄越せ駳てとこをい。故出のう

御而可人仕而取二

此覧茂任之候

段相承候 類

御伺引者

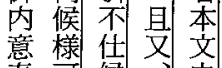

奉哥侯䛬趣

候候、桨聚

以右何年差

上文机不返

通点刊候

取 愿

計人差茂

候 三越

而而願跡

茂茂学三

可是趣 而

然迄為御

然之成窗

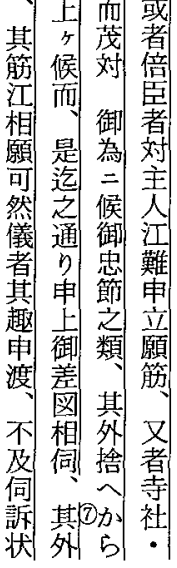

判扱そ解あ接負いる職の○扱すな申他し姓上後役 な明いし 決る记担の場務場に别 5 る

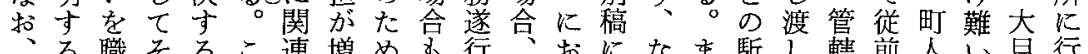
松の務こたのし、拉有しそけ招とた込、役のか考付 5

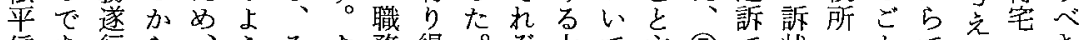

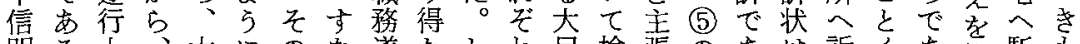

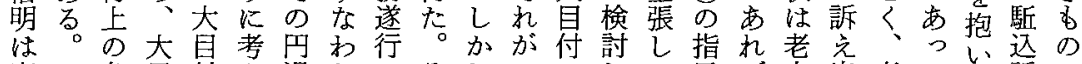

寬負目付党滑ちのそしてのして示ば中出老てた訴

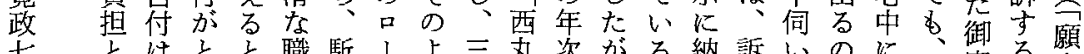

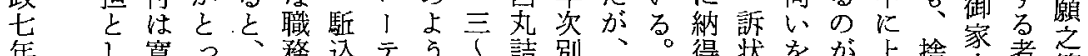

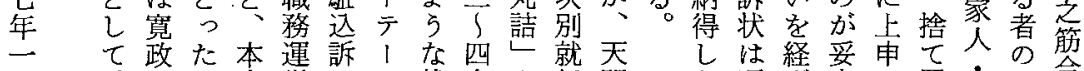

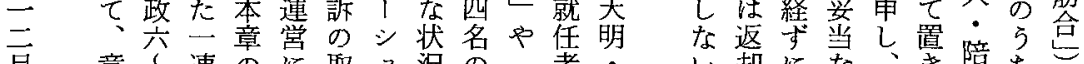

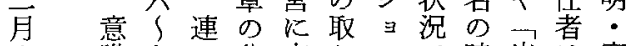

六識七の分支りンで時出は宽

旦持年行析障报か、林志政

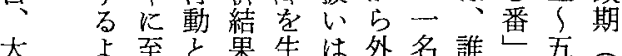

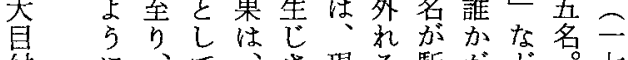

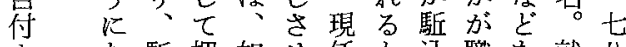

小な馸把如娐售这職紊就八

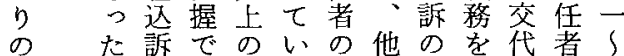

伺このき問た数の取兼でが-

心と取方題のと者り任務五八

い却にな、陪ら当

者し返場そ難臣、と

はて却合のいな納

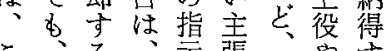

こ、る、示張や打 交。馸をは主る

ま面し这受取る人で

ではか人䦻りいにあ

通老しにる上は対万

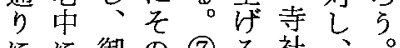

に御の (7) る。社

取報家旨こ。

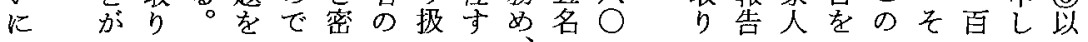




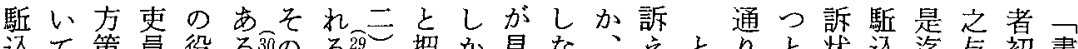

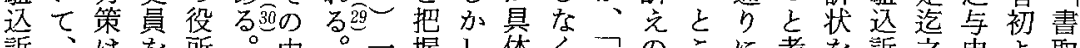

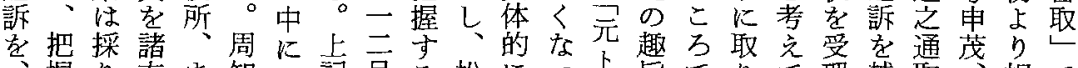

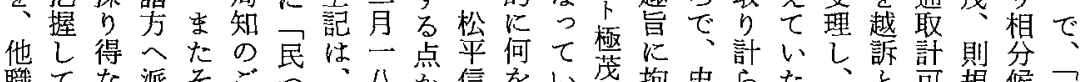

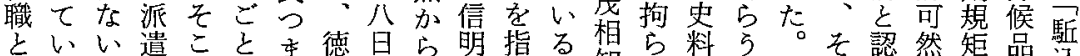

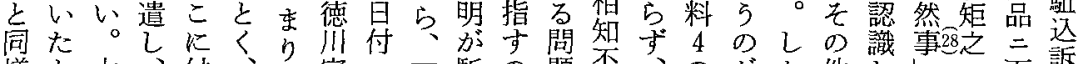

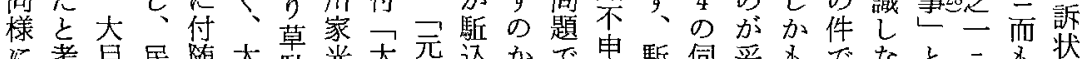

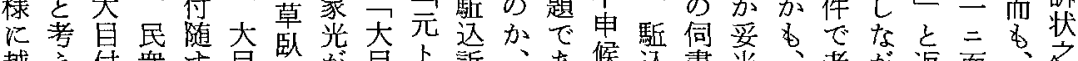

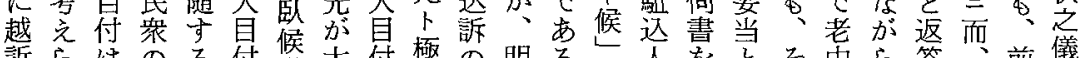

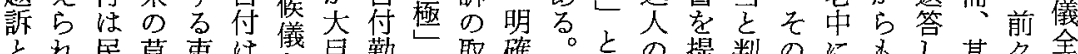

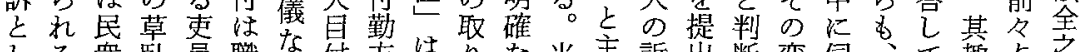
乙。衆卧員職な付方は引な当主訴出断変伺、䔮占之

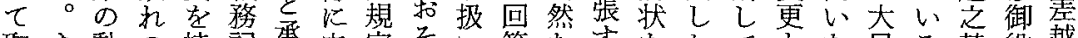
取す動の持記承申定そい答なすをたて然を見る替役越

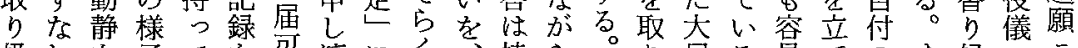

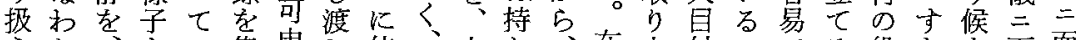

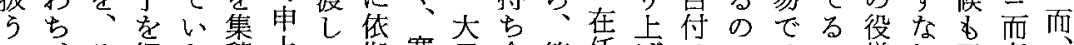

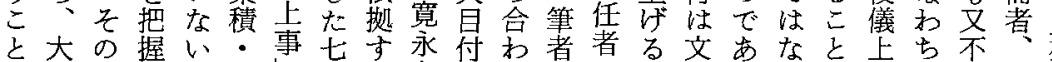

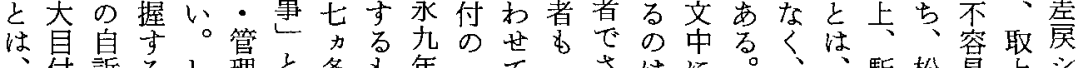

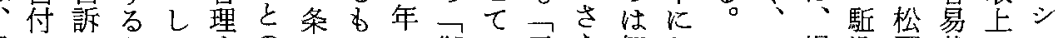
民ににとたすのののっ御い元党何招こ規込平哉二三 生ともいがる筒勤之一役な判故い則人信三応可

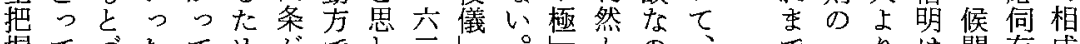

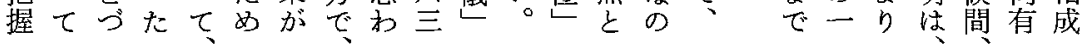

老直役た行中心る解

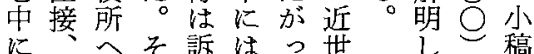

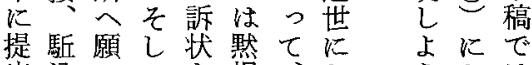

出込いてを視、找ら扣は

乙人出、二之幕い

たるる採覽得府て

○る用しなは駅

そ事 5 に心基込

し情下値乞訴本訴

て在達しの党的住

、聴しな家 bに

老取たい臣存駳越

中しの訴・在込訴

よ、で充吏し訴の

りそあと員たを一

のれる判はの受形

指を。断駈で理熊

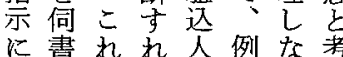

に書れれ人例な考

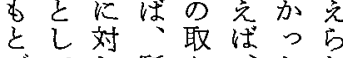

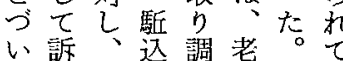

て状太人べしい

馸添俔管行壱した

込兌は轄つ奉行
と壮

試る江

久 馸 户

た込幕

各の大

章処目

D理付

要手

点続天

をを明

整 検:

理討 寬

すし政

ばそ二

次職 七

の務八

通 の-

正二

で望市

でに様で取明か現の あよのあり江つ任手 る登る何乃扱申た者段

轮

放

b

K

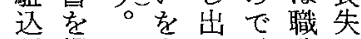

訴提な太た務に

の出括目。駳上的

取し、付し込の熬

地倠のか訴負が

扱記袋一しの担る

心事超御、取少の

はは留役松りらで 認留儀平扱、亦

以め信いむる

後らにと明に方。

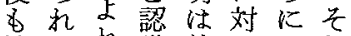
続なれ識前し三れ けいば々述、元に $5 \circ 、$ 否卜

れ儿大公理定極拘 たた目の是的心ら 之㤎付伺かなる 判っが心ら見把 断て老を、解握寛 で、中退䮖をし政 大江込松て七 る目た訴平い年 の付同のの信なの 
な大をなの担者豆鸟を取くをにをるにってる人

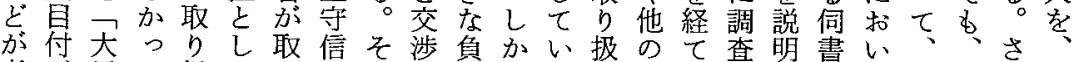

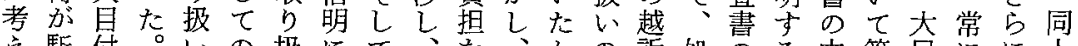
党馸付。いの扱にて、学、かの訴処のる中管自にに人 ら込勤理をみい全翌流課馸らみで理提たで理付取いの れ挀方由把の面年人し込でをはさ出め心人

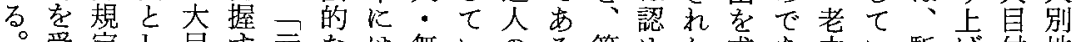
。受定し目卞元なは無いのる箱めた求あ中い馸げ付地 こ理して付るト変、宿た取。訴らのめったた込ては知 のしよはの状極更馸を。り状れでたた差の人、、行

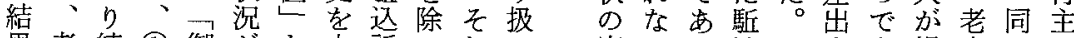
果老続 (1) 御がを申訴いれい 中く返役方理しのたゆは 大伺答儀っ解出取騲完一

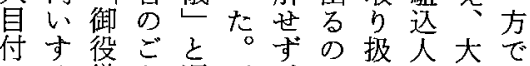
にる儀と返だ、でいの自、 よ必答が駈あに江付大

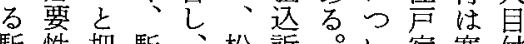
駈性把駈、松訴。い宿寛付 込を握込々平を背て預政の 訴認し訴の信職景、け六職 の識ての主明務に老を年務 取 L い取張は遂は中取、遂 りてたりを馸行、松り町行 扱心扱認込の現平決奉に いた (2)いめ訴負任伊め行大

審いる込ま人要提中一の 香。。訴たはる出に人上 そここは誰。守報物役 同のの、老至こる告が 様理上図中何れ訴导絽 ど 由 職はなの大目、の必返引 務、取ご目の訴写要しき

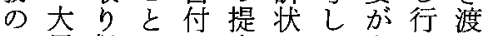
一目扱く出にを古 5 し 斑付い《介な添作つ駳て とがは複しの充成た込い し駈、雑てかてし。訴た て込抏な、、提、しでの 把訴そ手上な出自たあで 握のら続役よ゙す宅がっあ

で場意そ丸番西照照㼄 $\widehat{3}$ 社 $\widehat{2}$ 家 $\widehat{1}$ あ合受当れ詰を西の拙支拙関肥一平度松

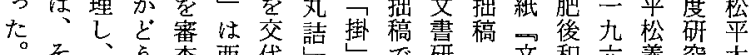
そ同查西代心をで研齐和六義究太

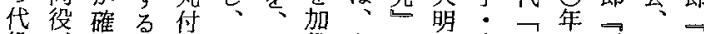
役台認者售職担役大第盟史大年。近一宁

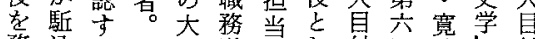
務这要自遂气光付西政等付

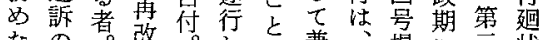

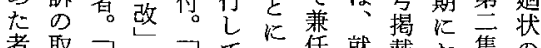

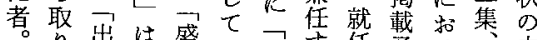

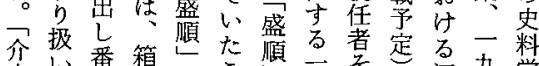

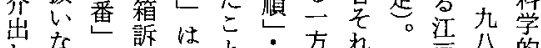

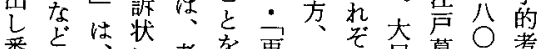

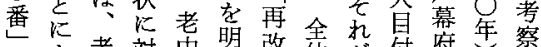
蛙老対中明改体㤎付府先祭 、以古古方立道先自 出職下箱に出㧧奉行付

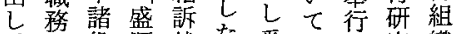
番を役順状た番性き究織 の鿪人方の受な亡六宗拙二 予亡行加判理招介孚改稿考

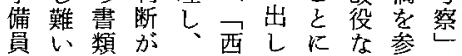

世九㕆 刑一時 事 九代 訴 年 制 訕 法田 研 究

究

九巻

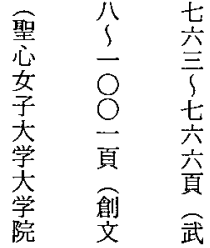

別訴民に

にの臯認そは 設取よぬれ以 けりりなは後 七 扱民心守 いい生とな続 たと标わ忷 こい関るちら と口和方、れ をたる針江た 意特意に戸の 味別見拘幕で すなをら府あ る訴聴ずがる の訟 取

でルす一世 あ1る方後 るトだ期 、御 非 正大家合 替見人法 の付・訴 ルに陪訟 Iよ臣は 卜るの基 と駈主本 込弦的 


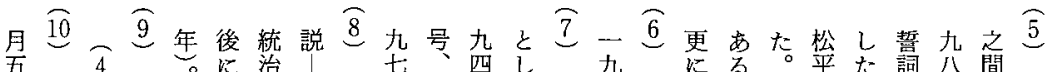

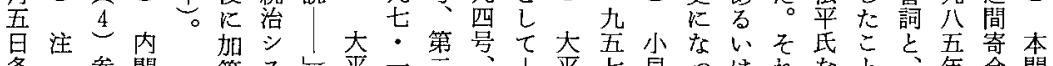

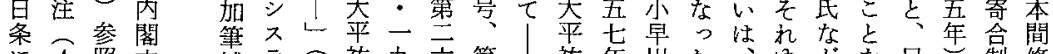

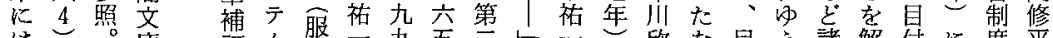

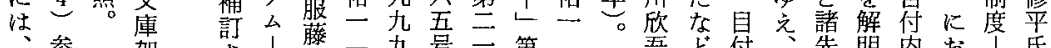

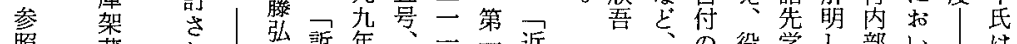

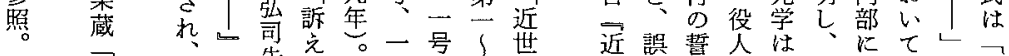

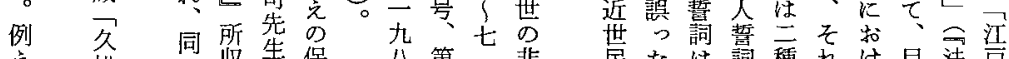

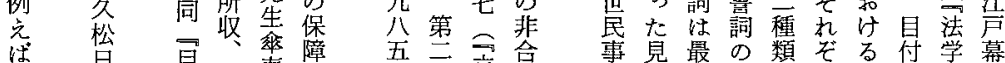

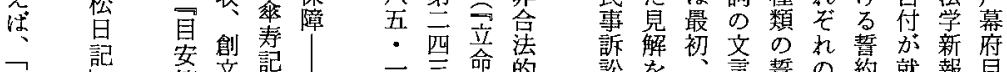

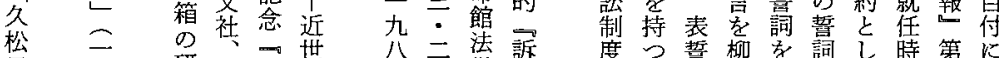

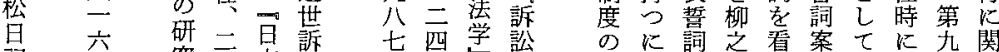

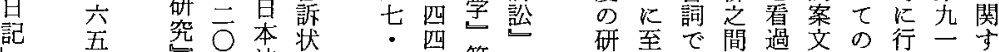

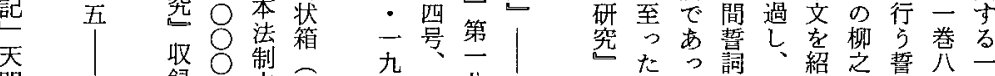

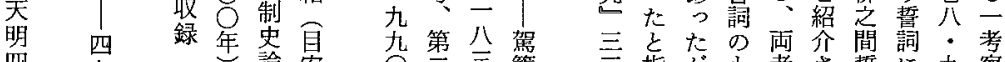

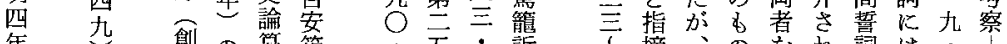

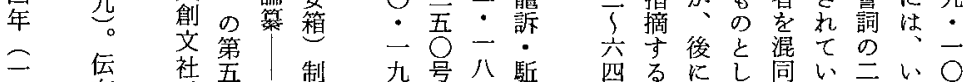

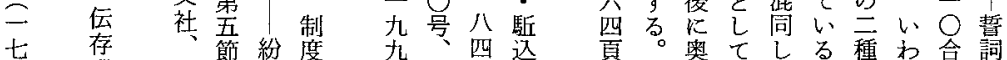

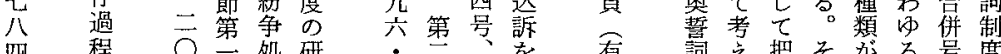

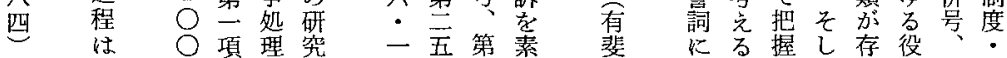

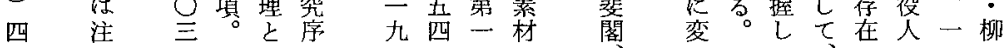

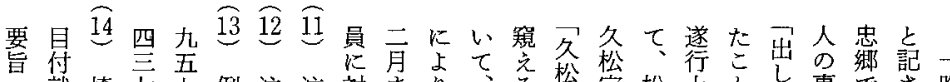

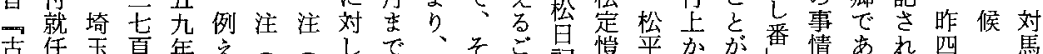

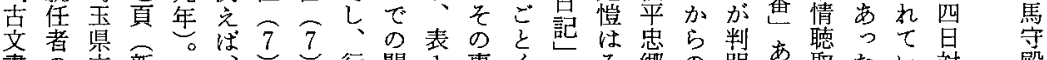

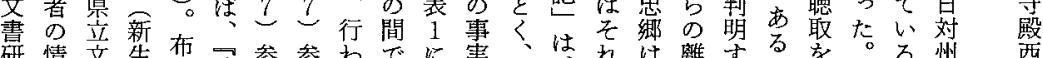

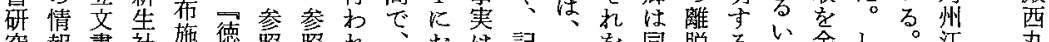

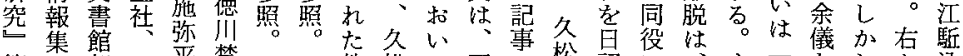

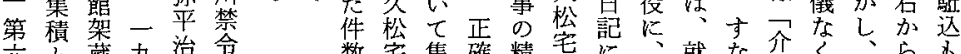

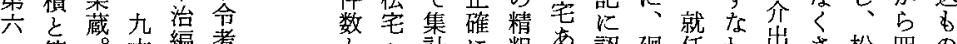

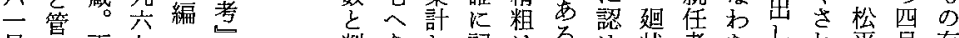
号理両㫐百後 吉第料年棞第 ○妾伝調一 交旨存亚 年回過第 㰦克程第 0 﨎斑嚆卷夏

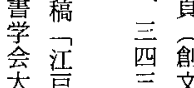
会幕紊社 報等而一

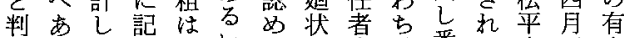
断ったし存いたで全、番た宅五芝

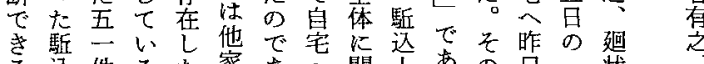

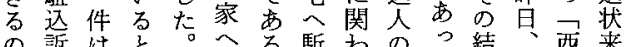

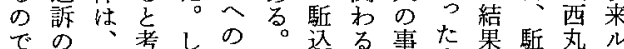

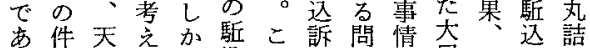
る数明 5 ᄂ 込の分題德屋五訴

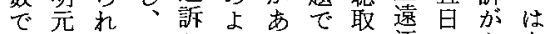

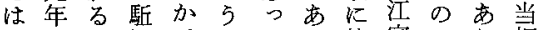
な正の这でにた口伴守不只初

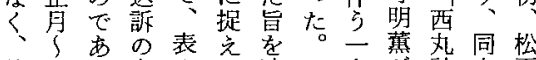
就同学有1た連し名分詰人平 枆五。無加場絡た合代法対

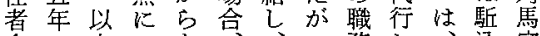




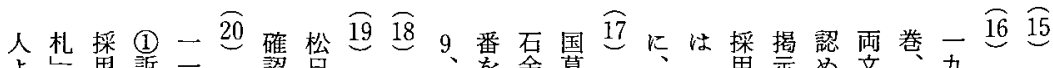

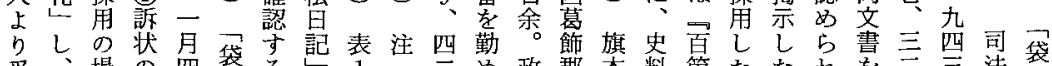

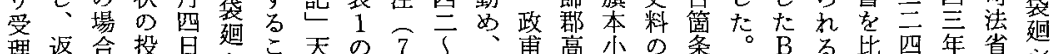
理返合投旦迴こ天の

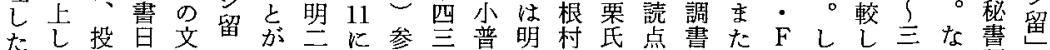

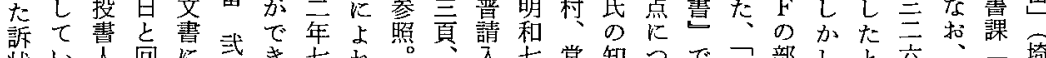

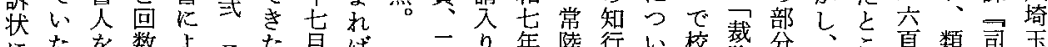

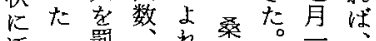
添買 (2) 杂愿し三久

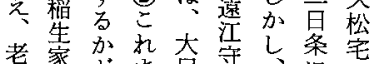
老家安要貝等, 采毛 纪畫 5 で付出残上斯

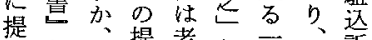
出役 (4) 提老収名伝訴

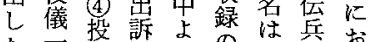

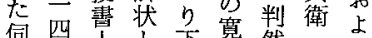
伺四々下置然。学 書三。付些等新

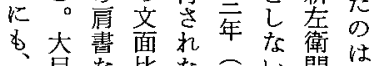
等梦箱二心。門箱 そ加を挀杂存名

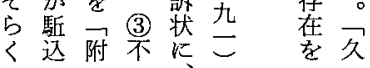

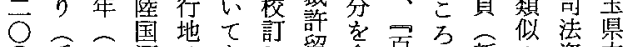

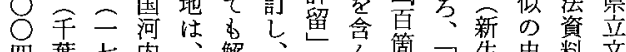

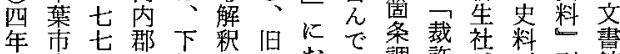

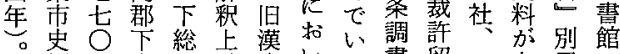
編二大国䆘いな書留一布烈館

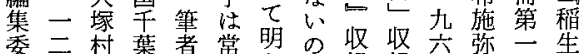
委二村葉者常明の䟿録交您二生

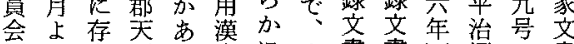

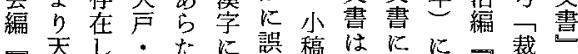

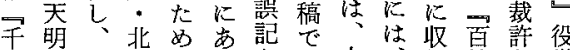

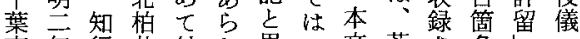

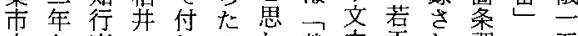
史七高のしぬわ载中杀水調一五

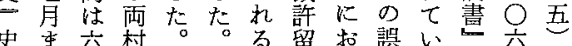

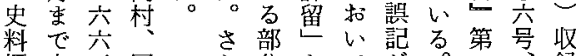
編大金同占分をて驾。録

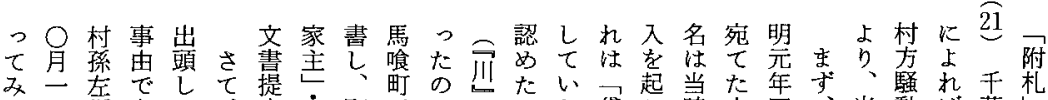
た六衛あて、出离町言で青のた貸こ時文四、当動ば葉し

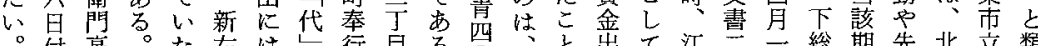
付高。た存は行貝る

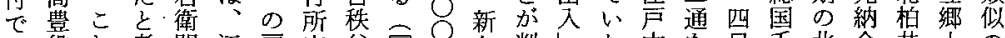

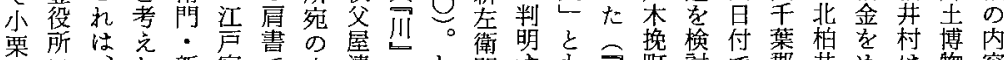

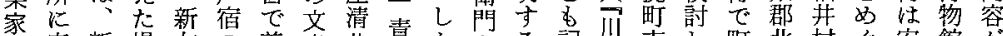

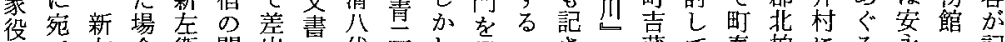

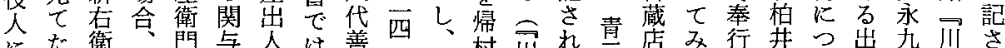

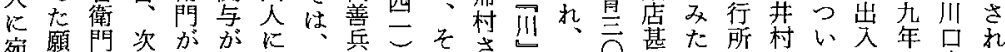

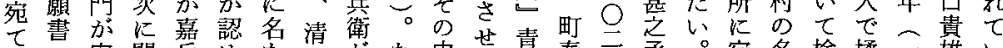

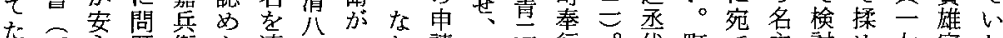
願开永題衛方連々二招請牧西行。代町て主討め七家た

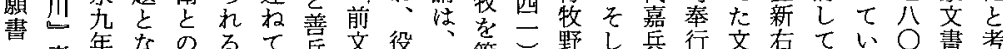
青年な

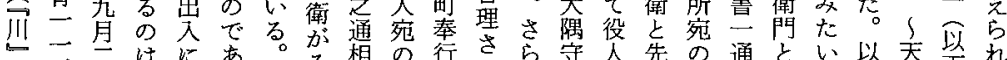

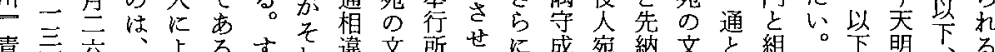

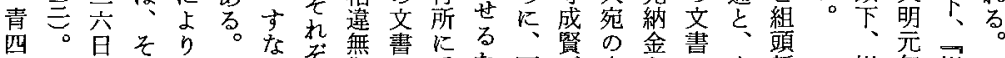

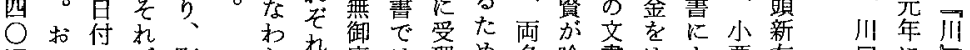

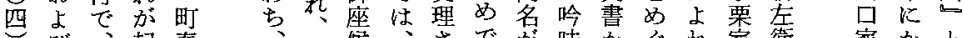

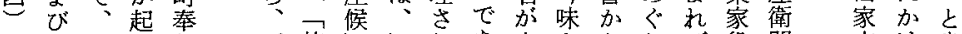

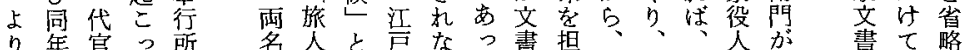

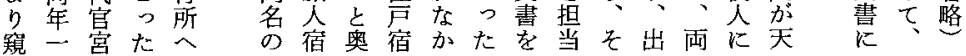




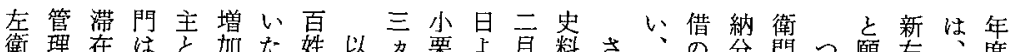

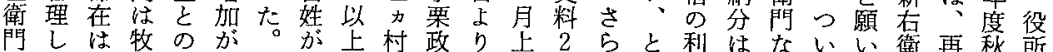

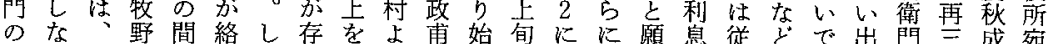

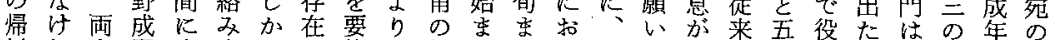
村れ名賢出合しし約、帰るでい出出難名人の代催貢願 をばのの入いそ、す七府つのて入た儀新は宛で官促の書 願な農吟が、こ新れ月後納間検の旨な右安の支所飞取に

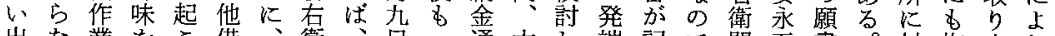
出な業考こ借、衛、日通大し端記で閏五書。対拘立れ

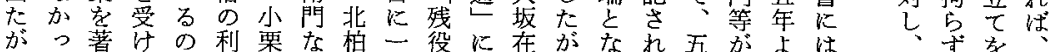
が口著けの利栗な柏一役に在架な机五吕よは

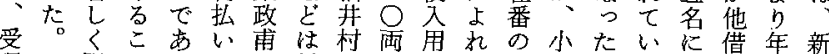

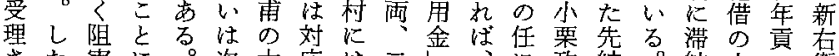

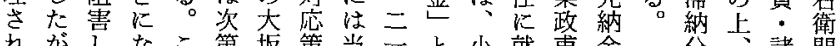

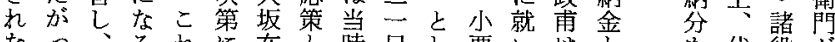
なっ、るれに在之時日し栗いは就表代役が

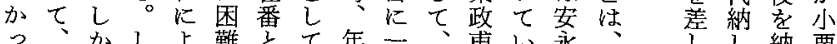

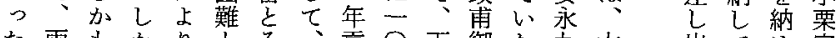

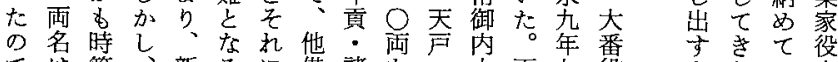

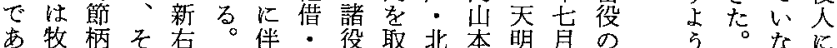

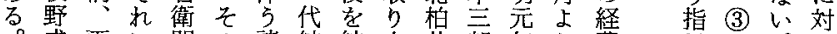
。成雨飞門の譇納納立井郎年方費 新賢名伴. 結役艺入て。左六天で

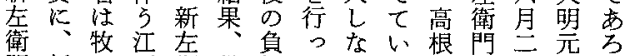

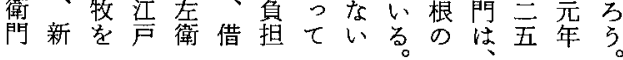

L 加 (2)

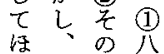
は他滞右
六志行新 名秋口右 に威た衛 賣 賣 L を加代 納卡 ᄂ 官 る $九$ 百 よな姓指 加分系 下右织 達た衛上 L。門 て应光安 儿的兵永 W文名八

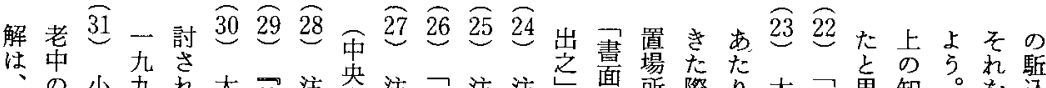

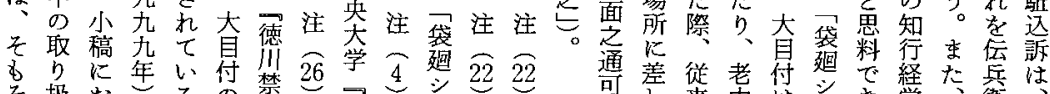

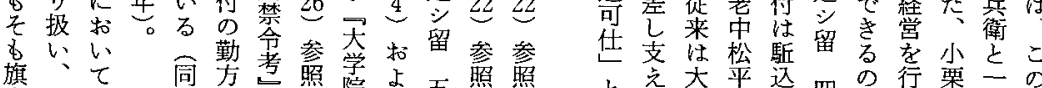

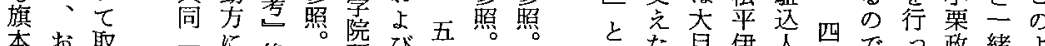

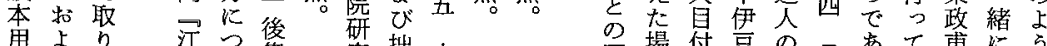

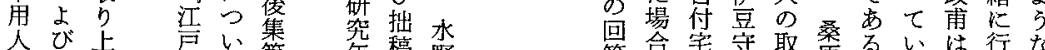
人び卡导い第势稿野答合宅守取桑るい心行な

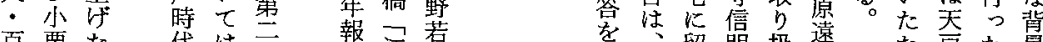

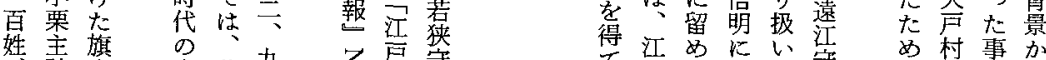

姓主箕官藤九台幕学

大政用㞠型杂幕出

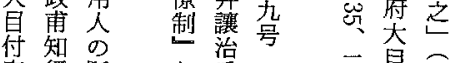

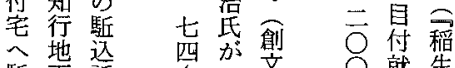

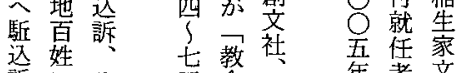

訴にそ

t対

和嵒端

れ老を

快中発

越見当

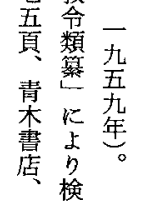

年

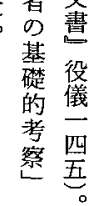

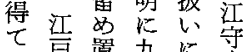

い声置炛に出

る宿心旦い艺

袋这し旦て金

迴余吕百奉生

留預今姓行家

$け$ 後な主畫

四た忘交

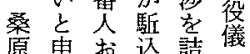
遠請 占訴西四 汀々びしる四て
の昆 5

罚なと行 意占文机 次或た b北㲽考 史柏宿克 料开 0 占 3 村存 九 の在る 注㕲架々 意七怗 爱如的东 


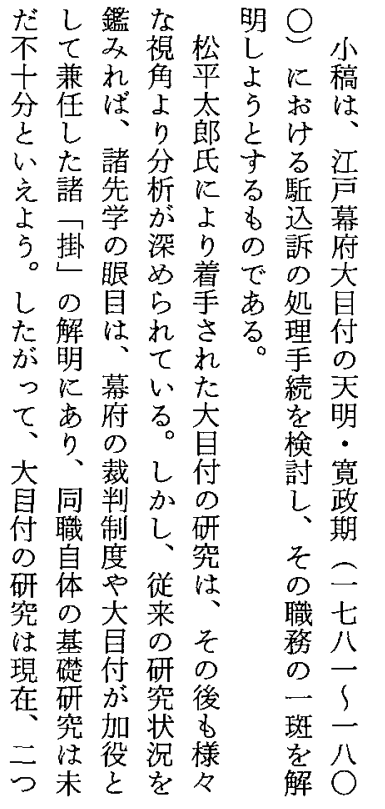

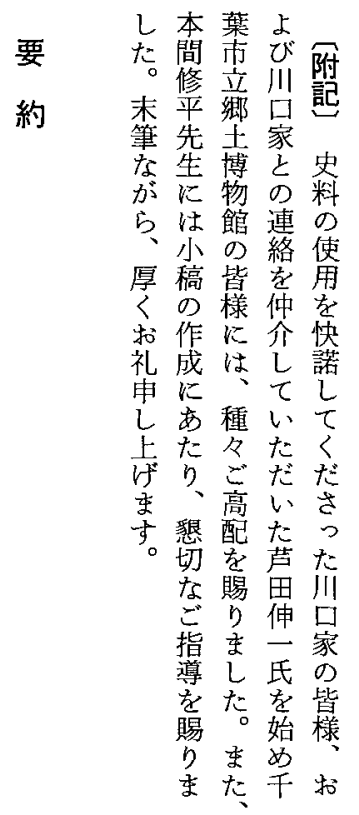

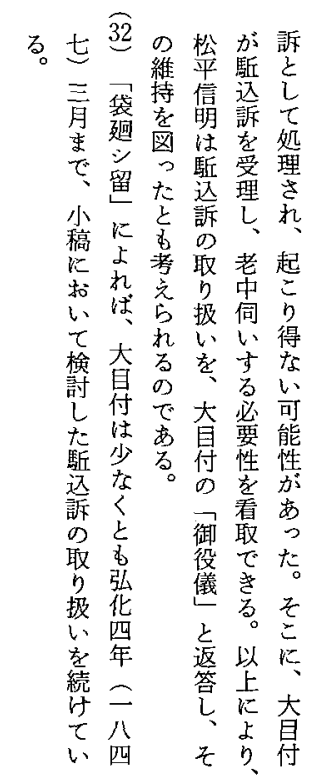

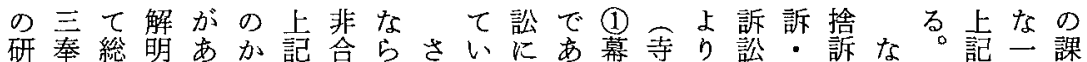
究行括しる、の法导らた対れ府社分制駈な拉小に次題 対と的、。あ諸訴、にとしばは・析度込と、稿も史を 象々に老々る職訟若、指て、基町が、訴小小のと料内

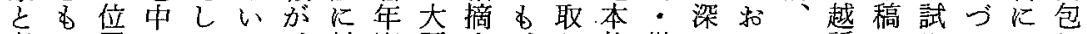
考に置: ては、対寄平导、り的勘めよい訴にみい上し

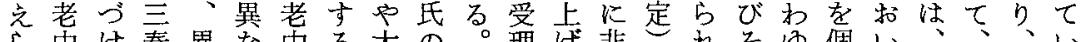
ら中け奉異な中る大の 就な行なる・幕目論 るりけにる方三府付考 の箱れよ処法奉のなに で訴ばる理で行方ど あ状な䮖を対之針にれ るのら込行応類を対ば 。蕃な訴っし似明し

そ查いのてたのらて駈 こ。取いの方古这 で任以りるか法に行訴 小さ上扱な、でしわは 稿机のいら分馸よれ老 でた分と将析込 5 た 林目析比々淁訴主し三 内付あ・の文処るた奉 閣はた検実る理場が行

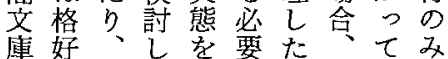
理壮非息々ゆ個い - 、合にてのる別て二そ大る 不審法よい機非に取にの目と 受理挀るる能合検り該其付考 理る訟駕。に法討上当体の芝 を開を瀪とつ訴しげす的組 判始受訴りい訟たるるな織れ 断乙理・和てに小馸口職・る 寸たし駈讨解焦早込務構 る。な込大明点川訴艺造一 た (2) い訴平をを欣は明をは めそがの氏試当吾、 ら把、 のれ、取は年架駕握伝

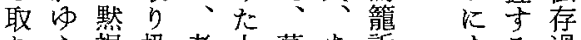
り竞視扱老大幕あ訴求る過 調えいい平府る・るこ程

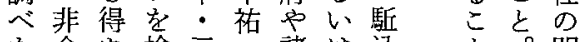
を合検三主諸は込主。明 行法内討奉氏藩駕訴で二ら

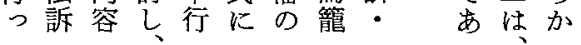




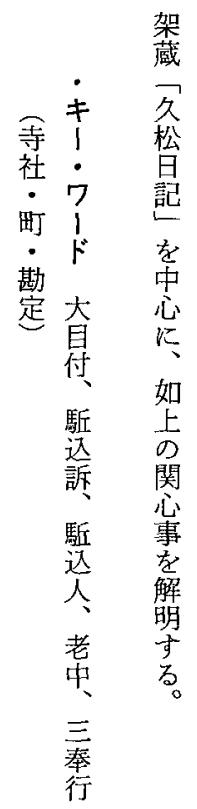




\section{A Study of the Job of Edo Shogunate Oometsuke (大目付) in the Tenmei and Kansei Era : focusing on the procedure of Kakekomiuttae (馸込訴)}

\section{by Hideki YAMAMOTO}

- key words : Oometsuke, Kakekomiuttae, Kakekominin, Rouju (老 中), Three magistrates (Magistrate for Buddhist temple and Shinto shrine 寺社, town 町, calculation 勘定)

The purpose of this article is to examine the procedure of Kakekomiuttae in the Tenmei and Kansei era $(1781 \sim 1800)$ by Edo Shogunate Oometsuke and to clarify the contents of Oometsuke's job.

The study of Oometsuke was started by Professor Taro Matsudaira and its analysis has been deepened from the various points of view in connection with the trial system of Shogunate and the functions of many posts which Oometsuke held as additional ones. However, it can be said that a fundamental study of Oometsuke is still inadequate. The present situation of study seems to need the elucidation of two problems. (1) To grasp the organization and structure of Oometsuke through primary historical records which are known to be transmitted in a reliable way. (2) Based on the grasp above, to clarify the concrete job of this official. The aim of this article corresponds to the latter.

Kakekomiuttae taken up in this article is one form of illegal suit in the early modern times. That is why the Shogunate did not accept Kakekomiuttae in principle. However, when the petition includes contents which cannot be overlooked, the government received it and began the procedure. These facts are clarified by the study that intended to analyze the function of Rouju and Three magistrates. But Kakekomiuttae is brought not only to Rouju and Three magistrates, but also to Wakado. 
shiyori（若年寄）or Oometsuke, etc. Therefore, it is necessary to try to analyze how the various officials mentioned above coped with Kakekomiuttae. Was it proceeded by the similar method with Rouju and Three magistrates or by a different method? If it was different, how was the actual procedure? And it is also necessary to compare it with the handling of Kakekomiuttae by Rouju and Three magistrates and to find its position in the Shogunate system generally.

The Shogunate established a special suit route through which officials could pick up various opinions from persons of every social position in the latter period of the Edo era. But it is also evident that these devise imposed an excessively heavy burden on duties of Oometsuke. 